\title{
COMMENTS
}

\section{THE FOREST AND THE TREES: SUSTAINABLE DEVELOPMENT AND HUMAN RIGHTS IN THE CONTEXT OF CAMBODIA}

\author{
ANDY WEINER ${ }^{\dagger}$ \\ INTRODUCTION
}

During the summer of 2001, I was an intern for the Land Unit of Legal Aid of Cambodia (LAC Land Unit), based in the capital of Cambodia, Phnom Penh. This Comment reflects thinking about the most significant case encountered by the LAC Land Unit over the course of that summer. The case involves a commitment of public forestland to a foreign investor for agro-industrial purposes. I measure its significance not merely by the number of clients affected or the amount of land at stake (though both figures would justify the label), but also by the global ramifications of the issue involved. It strikes me as paradigmatic of the fundamental problems facing Cambodia as a developing nation struggling to emerge from an antiquated agrarian economy incapable of providing for its future. What is happening in Cambodia further reflects nations around the world wanting to secure a position in the global economy. With this recognition, the following discussion aims at broader application than merely the Cambodian context; it endeavors to address an important issue of global concern.

' B.A. 1993, Bowdoin College; J.D. Candidate 2003, University of Pennsylvania. I would like to thank the people of Legal Aid of Cambodia who made this Comment possible. Of particular note, my appreciation goes to Francis James for the opportunity to spend the summer in Cambodia, to Max Howlett and Heidi Lichteveld for their friendship and introduction to the Cambodian NGO community, and to the members of the Land Unit, Yim Simene, Seang Boravy, Meach Sam On, Eang Sopheak, Am Sokha, and George Cooper, who were supportive in more ways than I can recount. I owe a debt to Professor Edward Rubin, Richard Weiner, and Jeffrey Waxman, who provided thoughtful feedback in the writing process. Finally, my thanks goes to Becky Haight, who was selfless in tracking down Cambodian sources. As is the mantra of all Articles Editors, mistakes are those of the Executive Editors of the University of Pennsylvania Law Review. 
As developing nations have little to offer by way of established industry or financial resources, they turn to their natural resources to entice investment.' However, these same resources represent the current foundation of their economies, on which nearly entire populations are dependent. The disturbing result of this dynamic is that industrial and economic development takes place at the expense of current generations.

The international community also suffers as a result of overexploitation by developing nations. Its current response entails a balancing of environmental, economic, and social influences expressed through the concept of sustainable development-broadly defined as "paths of human progress that meet the needs and aspirations of the present generation without compromising the ability of future generations to meet their needs." While the doctrine categorically remains a part of international environmental law, instruments including conventions, U.N. General Assembly resolutions, and treaties have increasingly viewed sustainable development through the lens of international human rights. ${ }^{3}$ The debate it triggered among scholars and policymakers surrounds whether this human rights approach to environmental protection gives rise to a "human right to environment." Beyond this threshold inquiry, there lies uncertainty over the exact nature of such a right and whether the whole human rights approach to environmental law is worthwhile in the first place.

This Comment frames the debate through the case study of Cambodia. It fleshes out the doctrine of sustainable development by examining the documents that embody its quintessential expression, the international agenda at work behind the concept, the potential for its realization through community resource management, and the context of current international law and human rights regimes. These considerations indicate that a human right to environment exists as a fundamental component of the complex doctrine of sustainable development. The choice made by the international community to invoke human rights in the environmental context-from its distinctive approach in international law focusing on the individual, to its termi-

\footnotetext{
${ }^{1}$ See imfra notes 38-42 and accompanying text (emphasizing the extent to which underdeveloped economies rely on exploitation of natural resources).

${ }^{2}$ Gro Harlem Brundtland, Our Common Future, in EARTH AND US: POPULATIONRESOURCES-ENVIRONMENT-DEVElopment 29, 29 (Mostafa Kamal Tolba \& Asit K. Biswas eds., 1991).

See infra notes 139-42 and accompanying text (discussing the convergence of international environmental policy and human rights perspectives).
} 
nology, to established specific rights-signals assent to its existence. Further, the unification of human rights and international environmental policy expresses a recognition that the two priorities are "inexorably linked." A human right to environment comprises an essential ingredient in the effective implementation of sustainable development. It elevates sustainable development from an expression of the international community's aspiration for the environment to a powerful constraint on unilateral state action in the form of rights held by communities of the state.

The problem is that the predominant viewpoint does not go far enough in acknowledging the existence or content of a right to environment necessary to achieve its role. Specifically, the human right to environment is commonly characterized as a strictly procedural right, if considered a right at all. This Comment makes the case that the current international legal regime enunciates a right to environment. It then endeavors to define the right, at the same time exposing the deficiencies of a strictly procedural conception. The Comment concludes by asserting a substantive component to the right, justified in light of the evidence relevant to international law and essential to instituting sustainable development on a global scale.

Part I introduces the agro-industrial project proposed for Cambodia's forestland and places the Cambodian example in the broader context of an environmental crisis faced throughout the developing world. Part II explores the doctrine of sustainable development as the response offered by the international community. It also supports community forestry as a strategy for incorporating the principles of sustainable development into forest management in developing states. Part III turns to the role of human rights in the effort toward sustainable development-namely, to empower the local communities that are best situated to achieve that goal. It begins with an account of why there is reason to doubt the existence of a right to environment despite explicit language to the contrary found in several widely endorsed international instruments. While a procedural formulation of the right to environment succeeds in reconciling the most perplexing criticisms that bring the right into question, it also undermines the potency of the right in serving its purpose. Final analysis determines that a substantive right to environment is both real and indispensable. It originates from a unity of established international human rights and a universal acknowledgement of the relationship between these

\footnotetext{
${ }^{4}$ WORld Comm'n on Env'T \& Dev., OUR Common Future 37 (1987).
} 
human rights and the environment expressed, most notably, in the flagship product of the 1992 Earth Summit-the Rio Declaration on Environment and Development (Rio Declaralion)." The Comment concludes by admitting that a substantive right to environment, at best, holds a tenuous position in the framework of international law. The current importance of a substantive right to environment far exceeds its prominence as a guide for state practice. Still, the modest form of the substantive right to environment exercises some degree of influence. Looking forward, it also leaves open the possibility of evolving into a definitive fixture of future international law.

\section{THE PHEAPIMEX CONCESSION}

\section{A. Summary}

In two separate contracts signed during 2000, the Cambodian Ministry of Agriculture, Forestry, and Fisheries (MAFF) granted an agricultural concession to Pheapimex Fuchan Cambodia Co., Ltd. (Pheapimex) over land totaling more than 300,000 hectares (the Pheapimex Concession)." Under their terms, the Royal Government of Cambodia committed this property to Pheapimex for agroindustrial development for a period of seventy years.

Later that year, on December 25, 2000, a public ceremony took place for the signing of an agreement between Pheapimex and the China Corporation of State Farms Group (China Corporation). The contract calls for the China Corporation to invest seventy million dollars for growing eucalyptus trees on the entire concession area and to construct a modern paper factory using the eucalyptus as raw material

"Rio Declaration on Enziromment and Development, U.N. Conference on Environment and Development, U.N. Doc. A/Conf.151/5/Rev.1 (1992) [hereinafter Rio Declaralion.], reprinted in 31 I.L.M. 874.

Chris lang, World Rainforest Movement, The Pulp invasion: The international Pulp and Paper industry in the Mekong Region 19 (2002). The first contract, the Pursat Concession Contract, granted Pheapimex 138,963 hectares of land in Pursat Province. Contract: Agricultural and Process Investment Between MAFF and Pheapimex art. 1 (Jan. 8, 2000) [hereinafter Pursat Concession Contract] (on file with author). The same parties signed another contract, the Kampong Chhnang Concession Contract, granting Pheapimex another 176,065 hectares of land in Kampong Chhnang. Memorandum from the I.AC Land Unit to File 2 (Aug. 2001) (on file with author). A hectare is 10,000 square meters or 2.471 acres. RANDOM HOUSE WEBSTER'S UNABRIDGED DICTIONARY 885 (2d ed. 1999).

\footnotetext{
${ }^{7}$ Pursat Concession Contract, supra note 6 , at arts. 1.1, 2.1.
} 
for its production. ${ }^{8}$ The significance of the project for Cambodia was marked by the appearance of the Prime Minister, Hun Sen, at the event."

Pheapimex has acquired a notorious reputation in Cambodia through previous concessions. The Cambodian Forest Concession Review Report issued the company a "black rating," indicating "very poor performance, unacceptable in all respects" and requiring "urgent action" in response to its conduct." This fact is all the more alarming considering that, prior to receiving its most current concession, Pheapimex already controlled 708,725 hectares in five Cambodian provinces.' With the latest addition, Pheapimex controls almost six percent of Cambodia's total surface area and almost ten percent of its forests. ${ }^{12}$

Under the Pheapimex Concession, Pheapimex can begin operations on 5000 hectares in the first year of implementation, ${ }^{13}$ including

${ }^{8}$ Dave Bloss, Chinese Firm to Plant Eucalyphus for Paper; CAMBODIA DAILY, Jan. 4, 2001 , at 8 .

${ }^{9}$ Find Investment Partners in Pine Growing and Paper Firm, RasmeI Kampuchea (Phnom Penh), Dec. 28, 2000, at 8.

10 Dep'T of Forestry \& Wildlife, Royal. Gov't of Cambodia, Cambodian FOREST CONCESSION REVIEW REPORT app. 8, tbl.IA (2000). In support of its rating of Pheapimex, the Cambodian Forest Concession Review Report detailed the company's various infractions. Pheapimex orchestrated extensive illegal logging throughout Kratie and Kampong Thom. Id. at app. 8, tbl.2. Outstanding charges awaiting inquiry and investigation included unauthorized cutting (on six separate occasions, two more than any other concessionaire), unauthorized export, and unauthorized road construction. Id. at app. 7, tbl.2. Beyond its failure to honor contractual obligations, Pheapimex threatened the lives of forestry officials attempting to enforce existing legislation against the company. Global Witness, The Untouchables: Forest Crimes and THE Concessionaires-Can Cambodia AFford To Keep Thlim? 8 (1999). Finally, Pheapimex also dealt harshly with more senior officials that stood in its way. The Director of the Forestry Department participated in meetings to discuss the company's lawless use of Cambodia's forests. Id. Before action could be taken, Pheapimex successfully lobbied for his removal in 1997. Id. This not only demonstrates Pheapimex's determination to preserve its modus operandi, but suggests the influence it wields in spheres of government. Pheapimex continues to enjoy favored status with the govermment despite its history. It is claimed that such impunity results from "the extremely close relations between the company's Cambodian owner . . and [Cambodian Prime Minister] Hun Sen." $/ d$.

"Global Witness, supra note 10 , at 7.

12 These figures are based on Cambodia's total surface area of 17,652,000 hectares and estimated total forest area of 9,335,000 hectares. Cambodia Couniry Profile, Food \& Agric. Org. of the U.N., at http://www.fao.org/forestry/fo/country/index.jsp?lang_ $\mathrm{id}=1$ \&geo_id=38 (last modified Dec. 31, 2000). The total area Pheapimex controls under concession, including the area subject to the Pheapimex Concession, exceeds $1,008,725$ hectares.

1:3ursat Concession Contract, supra note 6, at art. 3.2. 
area in two communes, Ansa Chambak and Kbal Trach. ${ }^{14}$ The Secretary of MAFF wrote to Pheapimex on March 27, 2000, authorizing the first year's operation and stating that "the land area does not involve the [local village people's] ownership." "The Secretary hedges that position later in the letter with the remark, "if any problems arise with local people... then the company should cooperate with the government to discuss the problem."

The conclusions asserted by the Secretary of MAFF are based on a broad survey of the concession area within Pursat Province, including the land covered by the initial stage of the Pursat Concession Contract. The Minister of MAFF for Pursat Province compiled this research when the concession was proposed in 1997 and described his findings. ${ }^{17}$ The majority of the concession area, including the 5000 hectares where it would begin, was classified as "damaged wood [land]," meaning it had little economic value. ${ }^{18}$ Additionally, the provincial minister negated any potential of the area to mature into forestland worth preserving due to overexploitation by unauthorized parties and the government's inability to invest the capital and technology required to instill proper management." Consequently, the provincial minister concluded that committing the land to agroindustry would ultimately benefit the region, offering new job opportunities, augmented consumer markets, and modern technology. ${ }^{20}$ All of this would come "without any bad effect[s] on the citizen[s] o[f] that area."21

The local inhabitants surrounding the first 5000 hectares of the Pheapimex Concession tell a different story about the area's importance and local dependence on it. The woodland earmarked for the

${ }^{14}$ These communes are located west of the Tonle Sap River in central Cambodia about 100 kilometers north of the capital, Phnom Penh.

Letter from Chan Tong Iv, Secretary of State, MAFF, to President, Pheapimex 1 (Mar. 27, 2000) [hereinafter Letter from MAFF Secretary of State] (on file with author).

${ }^{11 i} \mathrm{ll}$.

17 Letter from Em Samoeun, Chief of Pursat Province, MAFF, to Ros Sreng, Minister, MAFF (Aug. 13, 1997) [hereinafter Letter from MAFF Chief] (on file with author).

Is Id. at 2. The exact breakdown of the inspected area comprised 2700 hectares of land for homes, 11,200 hectares of paddy land, 500 hectares of crop terrace, and natural woodland subdivided between 20,800 hectares of big resin tree land, 10,000 hectares of woodland, 96,400 hectares of damaged woodland, 2200 hectares of semijungle, 14,700 hectares of multiwood land, and 400 hectares of grassland. Id.

\footnotetext{
1d. at 3 .

211 $I d$.

"Id.
} 
concession includes land traditionally used by 1108 families from the Ansa Chambak commune. ${ }^{22}$ Villagers use this land to graze buffalo and harvest forest products including resin, fruit, creepers, rattan, cassava, mushrooms, traditional medicines, firewood, and wood for building their homes. ${ }^{23}$ In addition to the loss of this land, the villagers are also concerned about the impact of the plantation on their fields. The concession threatens village dams depended on by villagers for agricultural irrigation and for their cattle, particularly in the dry season. ${ }^{24}$ The commune claims that the forest protects local inhabitants from floods, storms, and soil erosion. ${ }^{25}$ These problems caused by deforestation include only those considered by villagers and organizations focused on the specific circumstances of the Ansa Chambak commune. A complete list of the general consequences brought on by deforestation is significantly broader and well documented. ${ }^{2 i}$

Lack of viable access to the forest promises to cripple the surrounding villages. A case study performed by the Cambodia Land Study Project of Oxfam Great Britain in two nearby provinces demonstrates the inevitability of this result. ${ }^{27}$ The case study reports that landless families in the impacted areas were dependent on forest access

22 Minutes of Meeting at Adhoc on Pheapimex Land Development in Pursat and Kampong Chhnang (Mar. 9, 2001) [hereinafter Minutes of Meeting at Adhoc] (on file with author). The work of the LAC Land Unit, and thus the focus of this case study, concentrates only on the Ansa Chambak commune. I take the situation of Ansa Chambak as emblematic of the issues presented by the Pheapimex Concession for many affected communities, including the neighboring commune of Kbal Trach.

23 Letter from Lek Thung \& Um Hourt, People's Representatives, Ansa Chambak Commune, to NGO Forum 1 (Jan. 28, 2001) [hereinafter Letter from People's Representatives] (on file with author). These statements were confirmed by a joint investigation conducted by three nongovernmental organizations (NGOs)-Global Witness, the IAAC Land Unit, and Adhoc. Report on the Fact-Finding Mission to the Ansa Chambak Commune 5 (Mar. 13, 2001) [hereinafter Report on the Fact-Finding Mission] (on file with author).

${ }_{24}$ Memorandum from the LAC Land Unit to File, supra note 6 , at 5.

${ }^{25}$ Letter from People's Representatives, supra note 23, at 1.

24) For the effects of deforestation specific to Cambodia, see Jennifer Lynn Peters, Note, The Illegal Trafficking of Timber in Cambodia, COLO. J. INT'L ENVTL. L. \& POL'Y, 1999 Y.B., at 102, 105; Heather A. Wolf, Comment, Deforestation in Cambodia and Malaysia: The Case for an International Legal Solution, 5 PAC. RIM L. \& POL'Y J. 429, 431-33 (1996). For discussions of the effects of deforestation in general, see Mara Kimmel Hoyt, Note, Breaking the Trade Barrier: Common Property Solutions to Tropical Deforestation, 5 Minn. J. Global. Trade 195 (1996); Fermin Adriano \& Joel Adriano, The Fight to Save the Forests, BUSINESSWORLD, Nov. 19, 1999, LEXIS, BWorld File.

${ }^{27}$ SANETh VATHANA ET Al, OXFAM GR. BRIT., ACCESS TO FOREST RESOURCES AND LANDLESSNESS: CASE STUdies OF DEGRADED FORESTS AND LIVEllHOODS IN KaMPONG: Thom and Kampong ChHnang Provinces (2000). 
for one hundred percent of their livelihoods. ${ }^{28}$ Farmers with small landholdings and no livestock were seventy percent dependent on forest access. ${ }^{2 !}$ Even wealthier farmers included in the study proved twenty percent dependent on forest access. ${ }^{30}$ Furthermore, another case study by the Cambodia Land Study Project of Oxfam Great Britain demonstrates that most rural Cambodians depend on a diversified resource base for their livelihood. ${ }^{31}$ Thus, reduced access to common property such as a community forest undermines villagers' protections against production deficits in other endeavors, such as farming. Eliminating common property promises to impact the poorest families most severely because their dependence is the highest. It also renders wealthier families less secure in difficult times.

In March 2001, a meeting was held at the Ansa Chambak commune between village representatives and members of the provincial administration, including a provincial officer from MAFF and another from the Ministry of Environment. ${ }^{32}$ The villagers strongly objected to Pheapimex clear cutting the local forest and put forth the idea of instituting a community-operated tree-planting effort. ${ }^{33}$ During a factfinding mission to Ansa Chambak a few days later, village representatives were asked whether the entire community stood firmly against the clearing of the forest under the concession. They responded that they believed opposition was uniform.

The fundamental problem facing the Ansa Chambak commune, in a nutshell, is that despite its long and multidimensional reliance on the forestland covered by the Pheapimex Concession, it holds no legal claim of control to ensure forest preservation.

2x. at 4.

29) (ld. Farmers with small land holdings are defined as owning less than one hectare of land and no livestock. Id. at 8 .

31) Id. at 4. Wealthier farmers are defined as those with at least a cow, a cart, and a hectare of land. Id.

31 ROBIN BIDIJUlPH, OXfaM Gr. Brit., MAKING, the POOR MORE Visible: LANDLESSNESS AND DEVELOPMENT RESEARCH REPORT 8 (2000).

${ }^{32}$ Minutes of Meeting at Adhoc, supra note 22.

33 ld.

3e Report on the Fact-Finding Mission, supra note 23, at 2 ("When asked if the whole community [was] $100 \%$ against Pheapimex coming in to clear the forest the representatives said they believed so but could not be sure . ..."). 


\section{B. The Deforestation Dilemma as it Applies to the Pheapimex Concession and Underdeveloped States}

The dilemma faced by the Ansa Chambak commune is paradigmatic of the problem that many rural indigenous populations face throughout Cambodia and other developing nations. It is estimated that 350 million of the world's poorest people fundamentally depend on forests for their survival. ${ }^{35}$ In the 1990s, the world's forests declined at a rate of approximately 90,000 square kilometers per year, amounting to a loss of $2.4 \%$ of the world's forestland over the course of the decade. ${ }^{36}$ Almost all the deforestation that contributed to this figure took place in tropical forest regions including Africa, Asia, and Latin America." ${ }^{37}$ This is a result of the fact that " $[t]$ he economies of many underdeveloped or newly developing countries depend on natural resources." ${ }^{38}$ For these "cash-poor, resource-rich" countries," natural resources offer an easy means of attracting money to their economies."

35 WORL.D COMm'N ON FORESTS \& SUSTAINABLE DeV., Summary RePORT: OUR FORESTS, OUR FUTURE 14 (Ajit Krishnaswamy \& Arthur Hanson eds., 1999), available at http://www.iisd.org/pdf/wcfsdsummary.pdf.

3i U.N. Dep'T OF ECON. \& SOC. AFFairs, Global Challenge, Global. OPPORTUNITY: TRENIS In SUSTAINABLE DEVELoPMENT 12 (2002) [hereinafter Global. CHALLENGE, GLOBAL OPPORTUNITY], available at http://www.johannesburgsummit .org/html/documents/summit_docs/criticaltrends_1408.pdf. To provide a better conceptual image of the deforestation problem, a more dated calculation of global forest depletion estimates that between 1980 and 1995, 200 million hectares, an area larger than Mexico, was deforested. Nathalie Chalifour, Global Trade Rules and the World's Forests: Taking Stock of the World Trade Organization's Implications for Forests, 12 GEO. INT'L ENVTL. L. REV. 575, 580 (2000). In total, human effects on the world's forests have decreased forest cover by approximately one-third to one-half of what they once were. $I d$. at 579 .

${ }^{37}$ Global Challenge, Global Opportunity, supra note 36, at 12.

${ }^{31}$ Peters, supra note 26, at 103.

3:' Hoyt, supra note 26, at 198.

4" A more cynical view of mismanagement of state resources in underdeveloped countries looks to the agenda behind wasteful resource allocation. Public choice theory distinguishes between government actions based on public grounds and those based on private grounds. Public motives value community deliberation and general social benefit. Private motives, by contrast, pursue the satisfaction of individual preferences and, consequently, may ignore concerns about maximizing social good. John C. Dernbach, Sustainable Development as a Framework for National Governance, 49 CASE W. Res. L. Rev. I, 97 (1998). See, generally DANiel A. Farber \& PHILIP P. FRICKEY, LAW AND PUBlIC CHOICE 5-7 (1991) (outlining public choice theory, which "distinguish [es] public choice form [sic] theories of social choice (the study of collective decisionmaking processes) and theories of rational choice (any analysis postulating that individuals act rationally to maximize their preferences)"). From this perspective, mismanagement of state resources may be less the result of developing state desperation for foreign in- 
In no area of resource exploitation is this more readily apparent than in the international timber trade. Timber is a lucrative commodity that only becomes more profitable as the world's supply decreases and more nations add themselves to the list of timber importers." This, in turn, increases the significance of the timber industry to developing countries and undermines any incentive to protect their remaining forests. ${ }^{42}$ Thus, the timber trade assumes ever increasing importance to developing nations that act as suppliers, despite the recognition that "[d]eforestation creates economic hardships," the likes of which have already been discussed with regard to the consequences that loom if the Ansa Chambak commune is cut off from forest access.

vestment than the result of self-interest on the part of government officials and privileged constituents or supporters. Dernbach, supra, at 97-98. The Pheapimex Concession is certainly susceptible to accusations of private motives.

"See Peters, supra note 26, at 103 ("[A]s more countries are forced to import timber, the timber trade has become more lucrative. And, the more lucrative the business, the less likely underdeveloped countries and logging companies will be to stop or reduce their logging efforts.").

42. Id.

${ }^{43}$ Hoyt, supra note 26, at 197; see also $\mathrm{H}$. Jeffiey Leonard \& David Morell, Emergence. of Environmental Concern in Developing Countries: A Political Perspective, 17 STAN. J. INT'L L. 281, 285 (1981) ("In the longer term, natural resource depletion by governments and impoverished individuals is likely to cause even greater human poverty and suffering and to hamper severely economic development in the rural sectors of developing countries."). In the case of Cambodia, timber exports generate an estimated one hundred million dollars a year, representing forty-three percent of its foreign trade. Peters, supra note 26, at 104. In Cambodia's recent past, the government occasionally granted logging concessions under the auspices of agro-industrial projects. This allowed the government to claim that Cambodia's natural resources were going toward furthering permanent development. Concessionaires, however, would only use their allotted forestland for timber production and then abandon the project. Telephone Interview with Andrew Cock, Forest Policy Consultant, NGO Forum (Summer 2001) (on file with author). The Pheapimex Concession does not pose a threat of turning out the same way. The concession area constitutes forest unsuitable for logging. See supra text accompanying note 18 (describing the majority of the concession area as "damaged wood[land]"). Still, the potential remains that the agro-industrial project will not proceed as designed. Analysis by an independent forestry development specialist concluded that the Pursat Concession Contract "makes neither silvicultural nor commercial rational sense." Letter from P.D. Hardcastle, Forestry Development Specialist, to Max Howlett, Legal Consultant, LAC Land Unit 2 (June 13, 2001) (on file with author). Based on these findings, it is plausible to speculate that Pheapimex's objective is to "acquire land and influence rather than to grow pulpwood." Id. at 5 . In other words, Pheapimex may hope to profit through the rental of land for the seventyyear term of the Pheapimex Concession, Pursat Concession Contract, supra note 6, at art. 2.1, without establishing a paper industry in Cambodia. 
The timber trade is a popular target of blame for the deforestation problem, ${ }^{44}$ but it does not provide a complete explanation. Only one percent of the trees cut in tropical forests are intended for timber. $^{4.1}$ A more accurate account of the causes of deforestation points to a general effort by the governments of underdeveloped states to achieve growth. There are many culprits behind this forest loss, the greatest of which is not logging but the conversion of forestland for other purposes-for example, creating infrastructure, enabling settlements, or promoting industry and agriculture. ${ }^{46}$

This principal cause of deforestation is both international and domestic in nature. The Pheapimex Concession reflects how the international community contributes to deforestation. There is an incentive for private companies to invest in countries that offer low conservation standards, and thus, developing countries hesitate to protect their natural resources in order to remain attractive to industry. ${ }^{47}$ The domestic contribution to deforestation stems from the depletion of

${ }^{44}$ See, e.g., Chalifour, supra note 36 , at 580 (“[T] he clearing of forests in the process of logging timber also causes considerable loss of forested land."); Wolf, supra note 26, at 429 ("Logging is the primary cause of deforestation in Southeast Asia.").

45. Hoyt, supra note 26 , at 198.

4i Chalifour, supra note $\mathbf{3 6}$, at $\mathbf{5 8 0}$ (citing FOOD \& AGRIC. ORG. OF THE U.N., STATE OF THE WORLD's FORESTS 1999, at 1 (1999)). The FAO explains that, for developing states alone, agriculture is the single greatest cause of deforestation. FOOD \& ACRIC. ORG. OF THE U.N., supra, at 1.

${ }^{47}$ See Chalifour, supra note 36 , at 610 ("The possibility of losing business investment to other jurisdictions with less stringent forest management standards may cause a 'regulatory chill' or 'political drag' on sustainable forestry standards, or on regulations to set aside protected forest areas."); see also Hoyt, supra note 26, at 199-201 (citing incidentally detrimental effects of international aid, the global market's failure to reflect "replacement costs" of natural resources, and the inability of the international community to forge policies on economic development and environmental protection as three ways in which international forces contribute to deforestation). But see Int'l Inst. for Sustainable Dev., Ten + Ten: Successes and Failures, at http://www.iisd.org/ briefcase/ten+ten_contents.asp (last visited Feb. 18, 2003) ("Business is beginning to recognize its wider responsibility towards people, communities and the environment."). Attracting investment to small and poor countries by more productive means is a major concern of the United Nations, as demonstrated by the International Conference of Financing for Development in Monterrey, Mexico, in March 2002, which was dedicated to the issue. For a discussion of the conference's agenda, see Kofi A. Annan, Secretary General, United Nations, Lecture at the London School of Economics and Political Science: From Doha to Johannesburg by Way of Monterrey-How to Achieve, and Sustain, Development in the 21st Century (Feb. 25, 2002) (transcript available at http://www.johannesburgsummit.org/html/documents/sg_speech_ london_2502.doc). 
forest resources to satisfy the immediate needs of consumers-most notably for fuel wood as well as land for crops and grazing. ${ }^{48}$

As disastrous as allowing the disappearance of the forests in underdeveloped countries is, it is equally problematic for governments to set out to protect all forestland for the sake of preserving the agrarian practices of their people. On a practical level, the status quo is unsustainable. ${ }^{49}$ Cambodia offers a sharp example of the inevitable changes on the horizon. In the past twenty years, beginning with the ousting of the Khmer Rouge regime in $1979,{ }^{50}$ Cambodia's population has exploded from an estimated seven million ${ }^{51}$ to almost thirteen million. ${ }^{52}$ The dilemma this creates from a property and forestry perspec-

${ }^{48}$ Hoyt, supra note 26, at 198.

49. Calculations of global land use, such as that conducted by the World-Wide Fund for Nature, reveal a thirty percent deficit with respect to the amount of land required to sustain the world population's consumption. Nitin Desai, Under-Secretary-General for Economic and Social Affairs, United Nations, Statement to the Second Committee Introducing Item 98 (Oct. 29, 2001) (transcript available at http:// www.johannesburgsummit.org/html/documents/desai_statement_to_2ndcommittee $\% 2029$ oct.doc).

50 The Khmer Rouge was a Communist regime that seized power in Cambodia in 1975, embarking on a political revolution designed to instill a pure Marxist agrarian society. Under the direction of Pol Pot, the Khmer Rouge dismantled society, imposing on Cambodia's population brutal policies characterized by forced labor, egregious neglect of basic survival needs, and mass murder. The four years under the Khmer Rouge was a national catastrophe that, by some estimates, caused the death of at least 1.5 million people, though definitive records were not maintained. Cambodia was liberated from Khmer Rouge control by a Vietnamese invasion in late 1978. Veron M.Y. Hung, Cambodia, in Asia-PACIFIC CONSTITUTIONAL YeARBOOK: 1996, at 69, 69 (Cheryl Saunders \& Graham Hassall eds., 1998). For a detailed account of Cambodia during the reign of the Khmer Rouge, see Ben KIERnan, THE POL POT REgIME: RACE, POWER AND GENOCIDE IN CAMBODIA UNDER THE KrIMER ROUGE, 1975-79 (1996).

"il Project Hannah, Focus on Cambodia, at http://www.gospelcom.net/twr/ph/ profiles/cambodia.php (last visited Feb. 27, 2003).

CIA, THE WORL.D FACTBOOK 2001, at 86 (2001). On a global level, the population is anticipated to increase from 5.5 billion to 8.5 billion people within the next thirty years, with approximately ninety-five percent of that increase taking place in developing nations. G.F. Maggio, Inter/Intra-Generational Equity: Current Applications Under Intermational Latw for Promoting the Sustainable Dezelopment of Natural Resources, 4 BUFF. ENVIL. L.]. 161, 179 (1997). Commentators have singled out the rapid increase in the world's population as particularly important in considering future stress on the environment. See LYNTON KEITH CALDWELI., INTERNATIONAL ENVIRONMENTAL. POLICY 277 (3d ed. 1996) ("Population has been a sensitive issue at all international conferences where it was a relevant factor."); Bo R. Döös, Environmental Issues Requiving Internalional Action, in ENVIRONMENTAL. PRO'TECTION ANI) INTERNATIONAL LAW 1, 1 (Winfried Lang et al. eds., 1991) (describing the "rapid increase of the world population" as a "destructive development"). At the 2002 World Summit on Sustainable Development (WSSD), one observer called the central issue of population growth, "the elephant in the living room that no body wants to talk about." Kurt Shillinger, Earth Summit Delegates Siruggle 
tive is the land shortage that awaits the next generation ${ }^{53}$-a grave problem for an agrarian state devoid of industry and any other substantial alternative affording the means to make a living. On an ethical level, development bears important causal links with many economic and social rights. ${ }^{54}$ The significance of development in this regard is clearly acknowledged by the international community through the 1986 Declaration on the Right to Development, where development itself is defined as a human right."5 Therefore, while it may seem tempting to condemn the Cambodian government wholesale for entering into the Pheapimex Concession based on narrow macroeconomic thinking, it must be conceded that the total preservation of the forest and traditional agrarian life is both unrealistic and unjustified.

to Resolve Issues: Population Growth, Said to Be at Crux, Is Left off Agenda, Bosron GLOBE, Sept. 2, 2002, at A6. Another commentator held the United States and the Vatican primarily responsible for complete avoidance of the issue. Id.

53 VATHANA ET AL., supra note 27, at 10-11; see also Sheila Tefft, Cambodians Retum to Tough Land Disputes, ChrisTIAN SCl. MONITOR, Nov. 21, 1991, at 5 ("[T] he most explosive dilemma facing postwar Cambodia: land ownership."). Other factors that may contribute to undermining traditional land use includes increased consumption rates, corruption, inadequate education, inequitable land distribution, insecure land tenure, and international debt incurred by the government and industries. Chalifour, supra note 36 , at $581-82$.

${ }^{54}$ See Alexandre Kiss, Sustainable Development and Human Rights, in HUMAN RIGHTS, SUSTAINABle DEVElopMENT' AND THE ENVIRONMENT 29, 31-34 (Antônio Augusto Cançado Trindade ed., 1992) (demonstrating the significance of development in light of rights guaranteed by the International Covenant on Economic, Social and Cultural Rights (ICESCR), including the right to self-determination (Article 1(1)), the right to work (Article 6(1)), and the right to an adequate standard of living that incorporates sufficient food, clothing, and housing (Article 11)); see also infra text accompanying notes 234-36 (discussing the fundamental rights protected by ICESCR).

5.5 G.A. Res. 128, U.N. GAOR, 41st Sess., 97th plen. mtg., U.N. Doc. A/41/128 (1986). Despite hesitation by the United States, most evident in the declaration by the U.S. representation at the Earth Summit of 1992 that "[d]evelopment is not a right," the United Nations marched ahead in the opposite direction, as evident in the Rio Declaration and subsequent international instruments. By 1995, the U.N. Department for Policy Change and Sustainable Development observed that "divergence of opinion seems to be diminishing" with regard to the recognition of a human right to development. Greg Maggio \& Owen J. Lynch, Human Rights, Environmental and Economic Development: Existing and Emerging Standards in International Law and Global Society pt. III (Nov. 15, 1997) (unpublished manuscript, on file with author), available at http://www.ciel.org/Publications/olpaper3.html. 


\section{Sustainable Development}

\section{A. The Theory Behind Sustainable Development}

The international community has promoted sustainable forest management to resolve the competing concerns within developing nations that lead to deforestation. This expression was formulated at the United Nations Conference on the Environment and Development held in Rio de Janeiro in June 1992 (popularly known as the Earth Summit), ${ }^{56}$ primarily through the Rio Declaration. ${ }^{57}$ The Earth Summit unanimously adopted the Rio Declaration, arguably marking the "transition from international environmental law to the international law of sustainable development." Additionally, the Earth Summit promulgated two further variations on the theme of sustainable development. The first is the Statement of Principles for a Global Consensus on the Management, Conservation and Sustainable Development of All Types of Forests (Forest Principles), applying the doctrine of sustainable development to forests. ${ }^{5.9}$ The second is Agenda 21, ${ }^{60}$ a detailed account of policies designed to achieve sustainable development. ${ }^{\text {it }}$ The U.N. General Assembly subsequently endorsed the Rio Declaration. ${ }^{62}$ The succession of events-the conferences, the agreements

$5 ;$ The Earth Summit included representation from 179 governments as well as officials from U.N. organizations, private businesses, NGOs, scientific groups, and 18,000 grassroots environmentalists from 166 countries. Alexandre S. Timoshenko, From Stockholm to Rio: The Institutionalization of Sustainable Development, in SUSTAINABLE DEVELOPMENT AND INTERNATIONAL LAW 143, 151 (Winfried Lang ed., 1995).

57 Rio Declaration, supra note 5.

:* Alan Boyle, Codification of International Environmental Law and the International

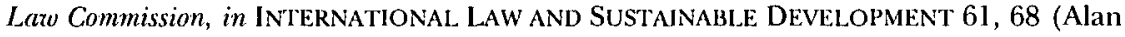
Boyle \& David Freestone eds., 1999).

50 Non-Legally Binding Authoritalive Statement of Principles for a Global Consensus on the Management, Conservation and Sustainable Development of All Types of Forests, U.N. Conference on Environment and Development, U.N. Doc. A/CONF.151/6/Rev.1 (1992) [hereinafter Forest Principles], reprinted in 31 I.L.M. 881. The Forest Principles calls itself the "first global consensus on forests." Id. at pmbl. (d).

(6) Earth Summit: Agenda 2l, U.N. Conference on Environment and Development, U.N. Doc. A/CONF.151/26/Rev.1 (1992) [hereinafter Agenda 21], available at http:// www.un.org/esa/sustdev/agenda21 text.htm.

6) See CALDWELL, supra note 52, at 110 (describing Agenda 21 as a "course of action for attaining environmentally healthy, sustainable and equitable conditions throughout the world").

${ }_{62}^{6}$ G.A. Res. 190, U.N. GAOR, 47th Sess., 93rd plen. mtg. (1992). Resolutions by the General Assembly constitute "recommendations" to member nations, nonbinding in formal legal terms. U.N. CHARTER art. 10. 
struck, and the support they received from the General Assemblyhas been called "the most significant universally endorsed statement of general rights and obligations of states affecting the environment."

In the ten years since the adoption and endorsement of the Rio Declaration, questions have arisen about adherence to the Declaration and the feasibility of implementing sustainable development. By all accounts, the actions and results that followed the Earth Summit fell well short of its promise. ${ }^{64}$ Taking stock of this situation at the 2002 World Summit on Sustainable Development (WSSD) in Johannesburg, South Africa, the world community reaffirmed its commitment to the Rio principles in its central product, the World Summit on Sustainable Development Plan of Implementation (Plan of Implementation). ${ }^{65}$ The WSSD aimed to clarify the concept of sustainable development, provide ways of meeting its standards, and update the focus of international efforts after ten years of experience and increased globalization. ${ }^{(i j)}$ None of these objectives entails a departure from the Rio Declaration or sustainable development as an international goal.

Sustainable use means "protecting the resource base and the environment for the benefit of future generations." ${ }^{67}$ By no means does this or any other single sentence capture its complexity. Rather, sustainable development embodies "a bundle of related concepts." It

${ }^{13}$ Boyle, supra note 58 , at 68 .

${ }^{\text {tit }}$ In his opening address to the World Summit on Sustainable Development (WSSD), Nitin Desai, the Under-Secretary-General for Economic and Social Affairs, spoke about the aftermath of the Rio Declaration, admitting that "we have not had the types of results that we ought to have had on the ground in relation to poverty, to the environment, and to risk management." Nitin Desai, Opening Address to the World Summit on Sustainable Development (Aug. 26, 2002), available at http://www .johannesburgsummit.org/html/documents/statements/2608_desai_opening_speech .pdf. For various perspectives as to why the Rio Declaration did not succeed, see Fred Pearce, Earth Summit: The Past Decade Has Seen Things Go from Bad to Worse, INDEPENDENT (London), Aug. 31, 2002, at 4; Normita Thongtham, Less Talk, More Action, BANGKOK POST, Dec. 4, 2001, http://search.bangkokpost.co.th/bkkpost/2001/ december2001/bp20011204/en/outlook/04dec2001_out04.html; The Breakdown of the Rio Bargain, Int'l Inst. for Sustainable Dev., at http://www.iisd.org/briefcase/ten+ten_ failures l.asp (last visited Apr. 30, 2003).

(i5 World Summit on Sustainable Dev., Plan of Implementation, para. 1 (2002) [hereinafter Plan of Implementation], available at http://www.johannesburgsummit.org/html/ documents/summit_docs/0409_plan_final.pdf.

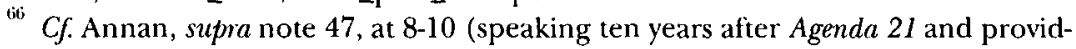
ing concrete examples of the impact of sustainable development).

${ }^{67}$ Agenda 21, supra note 60, 91 8.7.

${ }^{68}$ Dernbach, supra note 40 , at 6 . 
clearly stands for environmental protection but in limited measure, far short of absolute preservation. Indeed, sustainable development enables, and even encourages, development, provided that the environmental basis for future development is not inhibited." Viewed in this way, sustainable development strikes a conceptual balance between absolute preservation and wholesale exploitation of forests in developing nations.

The attention of the international community is the result of a combination of wide-ranging factors. ${ }^{70}$ For purposes of this Comment, it is important to focus on a few. Most obviously, the environmental impact of deforestation and other changes in natural ecology has global effects. Scientific data indicate several problems of deforestation to which the international community has responded with global concern." Among the most threatening ramifications include the contribution of deforestation to the irreplaceable loss of biological diversity and soil erosion impacting agricultural productivity, the poten-

(i) See Günther Handl, Environmental Security and Global Change: The Challenge to Intermational Law, in ENVIRONMENTAL PROTECTION AND INTERNATIONAL. LAW, supra note 52 , at 59, 80 (stating that the idea of sustainable development promotes development of a special qualitative nature). This conception of sustainable development is hardly without competition. Philippe Sands remarks that "[t]here exists no generally accepted legal definition of sustainable development." Philippe Sands, Intemational Laro in the Field of Sustainable Development: Emerging Legal Principles, in SUSTAINABLE DEVELOPMENT AND INTERNATIONAL LAW, supra note 56, at 53,58. However, Sands offers four components that he believes popularly identify sustainable development. These are the principles of (1) intergenerational equity, (2) sustainable use, (3) equitable use addressing the differing needs between states, and (4) integration of environmental objectives in development plans. Id. at 58-61.

${ }^{70}$ In the years leading up to the Earth Summit, the United Nations formed a World Commission on Environment and Development to explore the relationship between development and environmental degradation. The Commission found that countries' interests are inextricably bound to one another, creating a need for a multinational approach to resolving issues. WORLD COMM'N ON ENV'T \& DEV, supra note 4, at 37-41. The Earth Summit convened to respond to these conclusions. For a synopsis of the specific findings of the Commission, see Dernbach, supra note 40, at 19-21.

${ }^{71}$ See Luis E. Rodriguez-Rivera, Is the Human Right to Environment Recognized Under Intermational Law? It Depends on the Source, 12 Colo. J. INT'L ENVTL. L. \& POL'Y 1, 6 (2001) ("[A] broad consensus has developed among nations recognizing that global ecological interdependence mandates a coordinated international response to the serious environmental problems that threaten all of humanity."). See generally Int'l Inst. for Sustainable Dev., supra note 47, at http://www.iisd.org/briefcase/ten+ten. contents.asp (providing up-to-date information concerning the " $[\mathrm{m}]$ ajor advances . . made in the way we understand natural systems, and in the development of sustainable technologies"). 
tial for flooding, and regional climates. ${ }^{72}$ There are also indirect effects of deforestation identified through the linked causation and interconnectedness between broad groups of environmental harm. For example, deforestation trails only fossil fuel emissions as a major source of carbon dioxide ${ }^{73}$ that, in turn, produces climatic changes and reduces natural forests through temperature increases and rainfall fluctuations. ${ }^{74}$ Though knowledge of environmental dangers is far short of perfect, there is no doubt that the issues are profound. ${ }^{75}$

There is also a growing recognition of the relationship between poverty and environmental harm in which the poor both shoulder the considerable share of environmental burdens and apply significant pressure on the environment. The connection between poverty and bearing environmental harms is explained by a number of key considerations. First, seventy to seventy-five percent of the world's poor reside in rural areas of underdeveloped states. ${ }^{76}$ Second, poverty is a primary source of environmental degradation. ${ }^{77}$ Third, impoverished communities are least able to adapt to environmental change. ${ }^{78} \mathrm{Cam}-$ bodia illustrates this connection in reality. Not only are impoverished communities more commonly located in rural areas ${ }^{7 ! \prime}$ and more de-

${ }^{72}$ See Döös, supra note 52, at 33-34 (describing the damages caused by deforestation); see also Global. Challenge, Global. Opportunity, supra note 36, at 3-4 (describing entrenched poverty and development problems straining natural resources).

${ }^{73}$ See Döös, supra note 52, at 36 (comparing the effects of fossil fuel emissions and deforestation).

${ }^{74}$ See id. at 14 (predicting the ancillary effects of deforestation).

${ }^{75}$ See id. at 51 (arguing that, because the environment directly supports life, threats to the environment endanger "economic, social, political and military security").

Desai, supra note 49 , at 4.

${ }^{77}$ Edith Brown Weiss, Environmental Equity and International Law, in UNEP'S NEW WAY FORWARD: ENVIRONMENTAL LAW ANd SUSTAINABLLE DEVELOPMENT 7, 11 (Lal Kurukulasuriya ed., 1995); see also Leonard \& Morell, supra note 43, at 285 ("In the longer. term, natural resource depletion by governments and impoverished individuals is likely to cause even greater human poverty and suffering and to hamper severely economic development in the rural sectors of developing countries.").

${ }^{78}$ Weiss, supra note 77 , at 11 ; see also Kiss, supra note 54 , at 30 (describing the emergence of a favorable attitude among developing countries toward addressing the problem of development and environment as the result of factors including the link between environmental deterioration and poverty, and increased dependence on the environment among the poor).

$79.1 \%$ of the Cambodian population living outside urban areas are considered below the poverty line, compared with only $11.1 \%$ of the population of Phnom Penh and $29.9 \%$ of the population of other urban areas. MINISTRY OF PLANNING, ROYAL. Gov't of Cambodia, Cambodia Human Development Report 1999: Villace ECONOMY AND DEVELOPMENT 8 (1999) [hereinafter CAMBODIA HUMAN DEVELOPMENT REPORT 1999], available at http://www.un.org.kh/undp/publications/nhdr/1999.pdf. 
pendent on natural resources for their survival, ${ }^{80}$ but poor communities' ability to emerge from their economic conditions often requires an unenviable choice: inviting development and employment opportunities or preserving the environment." The Pheapimex Concession reflects one form of this choice. At one point, Pheapimex sought local support for its plantation by promising the Ansa Chambak commune a school building, construction of a road, and a small buffer between the plantation area and village farmland. ${ }^{42}$ On the surface, there may seem nothing unfair about such a proposition (to the contrary, it almost seems egalitarian) until one considers the basic needs the commune must choose between-land and present livelihood versus education and infrastructure. The option entails an unsettling sacrifice, irrespective of the direction the commune selects. ${ }^{83}$ Furthermore, as the example of the Pheapimex Concession demonstrates, the decision frequently lies not with the affected community, but rather with the state. Thus, even forward-looking communities, appreciative of their own reliance on the environment, do not necessarily ensure sustainable use of it.

The international community responded to the mutual pressures of poverty and environmental degradation in formulating the concept of sustainable development. Embedded in sustainable development is the requirement that "[a]ll States and all people shall cooperate in the essential task of eradicating poverty ... in order to decrease the disparities in standards of living and better meet the needs of the majority of the people of the world." ${ }^{8-1}$ The WSSD gave even greater prominence to the relationship between poverty and environmental harm by viewing poverty eradication in underdeveloped states as a central means of serving environmental sustainability. One report on the proceedings at the WSSD keenly observed that "[i]n Rio the aim was to protect the environment without damaging Third World development; this time it is to tackle poverty and underdevelopment with-

"Soe supra notes 27-31 and accompanying text (describing a land study project demonstrating the connection between forests and livelihood for impoverished groups).

See supra Part I.B (detailing the dilemma of cash-poor, resource-rich countries); see also Weiss, supra note 77, at 12 (objecting to the same choice between development and employment opportunities presented only to poor nations).

${ }^{82}$ Minutes of Meeting at Adhoc, supra note 22.

${ }^{83}$ See Weiss, supra note 77, at 12 (considering that such a choice "raises a question of fairness, for wealthier communities may not face that choice").

${ }^{84}$ Rio Declaration, supra note 5 , at princ. 5. 
out upsetting the environment." ${ }^{, 5}$ The Plan of Implementation reflects that thinking both explicitly, by calling poverty "the greatest global challenge facing the world today," and implicitly, by ordering poverty first among all of the issues related to sustainable development. ${ }^{81 i}$ Poverty eradication, it is fair to conclude, currently ranks first among priorities in the effort toward sustainable development.

The disparity in the harms incurred by environmental degradation operates not just among different economic spheres within individual states, but also among states themselves. The Rio Declaration acknowledges that "[ $\mathrm{t}]$ he special situation and needs of developing countries, particularly the least developed and those most environmentally vulnerable, shall be given special priority." ${ }^{\$ 7}$ This mentioned priority takes two basic shapes, both of which received new emphasis at the WSSD. First, the international community asserts through the Rio Declaration that the issues of environment and development should "address the interests and needs of all countries," providing developing countries comfort that the rising concerns over the environment would not severely threaten economic growth and industrial development. ${ }^{*}$ Second, developed states recognize that they make significant contributions to environmental harm through their demand for natural resources. ${ }^{90}$ Because of that, these states envision a significant role for themselves in current preservation efforts, irrespective of a forest's particular location. The Rio Declaration calls for a "global partnership" with regard to environmental protection implementation as well as policy. ${ }^{91}$ Principle 7 offers a clear expression of this pledge: "The developed countries acknowledge the responsibility that they bear in the international pursuit of sustainable development in view of

${ }^{85}$ Pearce, supra note 64.

${ }^{86}$ Plan of Implementation, supra note 65, at para. 6.

${ }^{87}$ Rio Declaration, supra note 5 , at princ. 6.

${ }^{88}$ I:

89 See Leonard \& Morell, supra note 43, at 282 (recounting a suspicion among developing states leading up to the 1972 United Nations Conference on the Human Environment in Stockholm that enthusiasm for international environmental protection would impede economic and industrial development). One representative of a developing state went so far as to exclaim, "let me die polluted," Kiss, supra note 54, at 30 , leaving no doubt of a preference to industrialize rather than to address environmental issues.

Developed countries are disproportionate consumers of resources. Most striking is the United States, which contains about five percent of the world's population but consumes about twenty-four percent of the world's energy production and almost thirty percent of the world's raw material production. Dembach, supra note 40, at 28 .

${ }_{91}$ Rio Declaration, supra note 5 , at pmbl. 
the pressures their societies place on the global environment and of the technologies and financial resources they command." the global partnership forged at Rio was built through a bargain between rich and poor countries: developing countries committed to guiding the use of their own natural resources by the principles of sustainable development, while developed countries contributed financial support, technology transfer, and opening trade channels that promised development through efficient resource use. ${ }^{93}$

The WSSD dealt with the unfortunate reality that neither campneither the developed states nor the developing states-lived up to its half of the bargain. Consequently, the wealth divide stands wider than ever both between and within countries." And globalization, with its trade and financial liberalization having the potential to foster global equity and further sustainable development, worked decidedly against these ends." The WSSD made it a priority to reverse the negative impact of globalization on sustainable development. U.N. SecretaryGeneral Kofi Annan called for the world to "face the uncomfortable truth ... [that the] model of development we are accustomed to has been fruitful for the few, but flawed for the many." Globalization exacerbated the sentiment at Rio that "[the richest countries] contribute disproportionately to global environmental problems." ${ }^{, 77}$ In response, the Plan of Implementation urges focus on the potentially positive outcomes of globalization-bringing trade opportunities, investment, capital, and technology to developing countries-in pursuit of both increased global equity and sustainable development. ${ }^{: 18}$

Finally, attention of the international community is the product of the evolving framework of international law that increasingly accommodates international interest in domestic policies of development and environmental protection. ${ }^{90}$ Günther Handl explains that the

Id. at princ. 7.

"3: Int'l Inst. for Sustainable Dev., supra note 64, at http://www.iisd.org/briefcase/ ten+ten_failuresl.asp.

Desai, supra note 64 , at 2.

See id. (discussing the negative impact of globalization).

"16 Press Release, United Nations, U.N. Secretary-General Calls for Change at Summit (Sept. 2, 2002), available at http://www.un.org/events/wssd/pressreleases/ highlevelopen.pdf.

Id.

I8 Plan of Implementation, supra note 65, at para. 45.

(19) Se Handl, supra note 69, at 85-86 ("Across-the-board, decision-making powers on matters that hitherto had been exclusively in the national domain are increasingly shared with other states or have completely devolved upon the international community at large."). 
idea of state sovereignty-and the residual right to utilize a state's environment as the state chooses-is a "functional concept." What this means is that sovereignty and the freedoms it grants contain limits defined not by individual states but by the community of states. The international community of states creates the legal basis upon which an individual state can exclude intervention, as well as the basis for which the international community can assert input. ${ }^{101}$ The concept of "sustainable development" is one such example. It establishes a platform on which the international community reserves the right to participate in national decisions regarding natural resources. In other words, sustainable development "intimate[s] limits on nation-states' freedom of action for the sake of protecting the larger [international] community interest at stake." ${ }^{102}$ At the same time, the doctrine of sustainable development hardly eviscerates sovereignty over state resources. Handl considers that states retain significant autonomy to administer their natural resources through the standards for measuring sustainable development, which come from the states as opposed to some international norm. ${ }^{103}$ However, other commentators warn, " $[\mathrm{t}]$ he time is near when states will no longer be permitted by the international community to rely upon claims of state sovereignty to avoid their responsibility to the world at large to protect the environment within their national borders." to implement this policy of global environmental sustainability.

\section{B. Community Forestry as a Practical Face of Sustainable Development}

Among the most promising means of promoting the international agenda of sustainable forest management is through community forestry." "Community forestry is a strategy for sustainable forest man-

1001 Id. at 87 .

101 See id. at 85-87 (discussing the contours of state sovereignty in the modern world).

102 Id. at 86 .

108 If. at $85-87$.

1014 J.D. van der Vyver, Property in International Human Rights Lazu, in PROPERTY LAW ON THE THRESHOLD OF THE 2 IST CENTURY 451, 475 (G.E. van Maanen \& A.J. van der Walt eds., 1996).

${ }^{105}$ Community forestry is one application of the larger scheme of community resource management with applications to a spectrum of natural resources including fisheries, irrigation water systems, pastures, and wildlife-hunting territories. Fikret Berkes \& M. Tagho Farvar, Introduction to COMMON PROPERTY RESOURCES: ECOLOGY And Community-Based Sustainable Devel.opment 1, 3-7 (Fikret Berkes ed., 1989). 
agement through the participation of rural people, by making the objectives of rural people central in forest management and ensuring that rural people obtain reasonable benefits from forest management." ${ }^{106}$ It accommodates the goals of environmental stability, a substantial measure of economic growth, and cultural survival. ${ }^{107}$ As a result, "[c]ommunity resource management has become a significant theme of rural development strategy throughout Asia," ${ }^{108}$ and there is no reason to think its application cannot enjoy success among developing nations on a broader level.

The fundamental principle that underlies the promise of community forestry to produce positive environmental, economic, and cultural ends is that these goals are attainable only through improved resource management. ${ }^{109}$ That requires control over both the access and use of forestland. ${ }^{110}$ Most forests in developing nations are owned by the state. "I While states retain the authority to regulate the use of forest resources, they severely lack the capacity to do so. ${ }^{12}$ Local villages, on the other hand, rely heavily on the forests in their daily lives and account for the lion's share of use. ${ }^{13}$ Customary use fosters a sense of authority in accessing the forest, ${ }^{114}$ but not in preventing others from doing likewise or even curbing their own exploitation of resources. The lack of any formal control of the forestland dictates that self-interest, as opposed to the community's interest, will prevail. The

For general discussions of common property regimes, see DAVID BROMLEY, ENVIRONMENT AND ECONOMY (1991); Berkes \& Farvar, supra.

${ }^{1 \text { hi }}$ Sustainable Forest MGMt. Project, ASIAN Dev. Bank, Community Forestry Guidelines 1 (1999) [hereinafter COMMUNITY FoREstry Guidelines] (on file with author).

${ }^{117}$ See Hoyt, supra note 26, at 212 (discussing "common property alternatives" and their goals).

Jis Jeff Romm, Frameatorks for Government Choice, in COMMUNITY MANAGEMENT: Asian Exibrience and Perspectives 225, 225 (David C. Korten ed., 1986).

lie: Id. at 226-27.

111) Id. at 227.

111 WORld RES. InSt. ET AL., TROPICAL FORESTS: A CAll FOR ACTION 10 (1985).

${ }^{112}$ Romm, supra note 108, at 227. Cambodia's government demonstrates particular weakness in this regard. The country obtained a pledge of $\$ 1.35$ billion for economic development from donor nations conditioned on Cambodia's ability to curb its illegal timber trade. In spite of strong financial incentives to comply, Cambodia's govemment has not met with success, and aid has been suspended several times. Peters, supra note 26 , at 109 .

${ }^{113}$ Romm, supra note 108, at 227; see also supra notes 28-31 and accompanying text (discussing dependence on forests by local villages in Cambodia).

${ }^{114}$ See Romm, supra note 108, at 227 (noting that this "separation of ownership and use" produces a situation in which no one is in control). 
incentive lies with reaping as much benefit from the forest in the shortest period of time because everyone else is operating under the same self-interest. Of course, such unrestrained forest use has the universally detrimental effect of depleting resources. Forest use at the individual level reflects the classic tragedy of the commons. ${ }^{115}$ Jeff Romm summarizes this situation: "In this nebulous separation of ownership and use, neither the villages nor public authorities could control these resources sufficiently to increase their productivity or reduce the larger consequences of their degradation."116

Instilling a community with a sense of joint ownership constitutes a step toward resolving the degradation that arises from insufficient control of forestland. ${ }^{17}$ There are also certain characteristics of local communities that further support environmental stability. These include: (1) an intimate knowledge of the ecosystem to be managed; (2) traditional patterns of use and foraging that foster productivity and renewability of the resources; (3) community organization to oversee the regulation of the forest coupled with a collective interest in upholding the rules set for its use; and (4) community values and a recognition of dependence that emphasizes responsible management. $^{114}$

${ }^{115}$ From a property perspective, a lack of adequate oversight of publicly accessible land means

$[t]$ he benefits of exploitation flow to individuals and institutions that do not pay the full costs of their activities. The circumstances are often correctly described as a "tragedy of the commons," in which the failure of restrictive mechanisms results in conditions of open access, over-exploitation of resources, and imposition of costs on persons who do not reap the benefits.

Lee P. Breckenridge, Protection of Biological and Cultural Diversity: Emerging Recognition of Local Community Rights in Ecosystems Under Intemational Environmental Lavu, 59 TENN. L. REv. 735, 752 (1992) (citation omitted).

116 Romm, supra note 108, at 227.

${ }^{117}$ Vandana Shiva et al., Social Forestry for Whom?, in COMMUNiTy MaNaGement: Asian EXPERIENCE AND PERSPECTIVEs 238, 242 (David C. Korten ed., 1986).

${ }^{118}$ Breckenridge, supra note 115 , at 746-48. Many of these points are identified individually by other commentators. For example, Vandana Shiva, H.C. Sharatchandra, and J. Bandyopadhyay stress the point of community organization, stating that " $[t]$ he survival of such community property . . . is only possible under a social organization where checks and controls on the use of resources are built into the organizing principles of the community." Shiva et al., supra note 117, at 242. Similarly, Marianne Schmink, Kent Redford, and Christine Padoch identify a strong community interest in sustaining natural resources through the explanation that, " $[\mathrm{t}] \mathrm{o}$ the extent that their survival, and that of their children, depends on the future of the resources in that same site, local communities may have a built-in incentive to use natural resources sustainably." Marianne Schmink et al., Traditional Peoples and the Biosphere: Framing the Issues and Defining the Terms, in CONSERvation OF NeOtropical Forests 3, 8-9 (Kent H. Redford \& Christine Padoch eds., 1992). 
More efficacious forest management also creates positive economic effects. It promotes the realization of the economic potential of forest resources without the overexploitation that sacrifices sustainability for short-term considerations. ${ }^{19 !}$ In one sense, it may be thought that such restrained behavior demonstrates how community forests are "not wholly governed by the market calculus we associate with developed societies." ${ }^{21}$ Underlying this point is the idea that " $\left[\right.$ w] hat constitutes development is largely subjective." ${ }^{121}$ Putting forest resources in the hands of those most dependent on them better assures that their allocation responds to the basic needs of that community, as compared to economic measures oblivious to particular social circumstances.

In another sense, community management correctly turns its back on maximizing present value. As the discussion of the Pheapimex Concession indicated, the destruction of forests generates costs well beyond the loss of trees. Also destroyed are valuable protections for neighboring agriculture, grazing land, and the products that can be harvested from the forest. ${ }^{122}$ These are but a few of the external costs that must contribute to the calculation of economic gain from unsustainable forest management. ${ }^{12 \cdot 3}$ The Forest Principles identifies the need

119) Hoyt, supra note 26, at 212-13.

120) Schmink et al., supra note 118 , at 8 . The Forest Principles attempts to bring validity to methods of project assessments that are not strictly economic, stating that "[d]ecisions taken on the management, conservation and sustainable development of forest resources should benefit, to the extent practicable, from a comprehensive assessment of economic and non-economic values of forest goods and services and of the environmental costs and benefits." Forest Principles, supra note 59, at princ. 6(c). In preparation for the WSSD, a series of regional roundtables took place to uncover issues and proposals surrounding sustainable development. Among the common issues identified was the problem that "growth is only valued in terms of financial and manufactured capital without properly reflecting value and depreciation of human and natural resources." U.N. SECRETARIAT OF THE. WORID SUMMIT ON SUSTAINABLE DEV., SECRETARIAT OVERVIEW OF THE WSSD REGIONAL. EMINENT PERSONS ROUNDTABles 5 (2001), available al http://www.johannesburgsummit.org/html/documents/ regionalround.huml. A proposal coming out of these roundtables was the development of a global approach toward internalizing nonfinancial costs. Id. The specific encouragement of commumity-based forest management systems in the Plan of Implementation offers one approach to achieve this end. See Plan of Implementation, supra note 65 , at para. 43(h) (calling on governments and communities to "[r]ecognize and support indigenous and community-based forest management systems").

${ }^{121}$ The Realization of the Right to Development: Global Consultation on the Right to Development as a Human Right, U.N. GAOR, Hum. Rts. Comm., Il 155, U.N. Doc. HR/PUB/ $91 / 2(1991)$.

Sipra notes 23-26 and accompanying text.

${ }^{123}$ See, e.g., Robert J.A. Goodland, Neotropical Moist Forests: Priorilies for the Next Two Decades, in Conservation of Neotropical Forests 416, 419 (Kent H. Redford \& 
to consider such costs for more accurate cost-benefit analysis of forest use. $^{124}$ Furthermore, to have adopted a policy of sustainable management means that comparison with unsustainable projects is "inappropriate." ${ }^{12.5}$

The prospects of community forestry as a method to achieve sustainable management have not escaped international attention. ${ }^{126}$. Principle 5(a) of the Forest Principles explicitly promotes shared authority over forests between local communities and the state. ${ }^{127}$ In addition, the Rio Declaration and the Forest Principles present parallel provisions implicitly paving the way for community forest management. They instruct states to share access to information relevant to the environment, ${ }^{124}$ enable both individuals and states to participate in the decision-making process on environmental issues, ${ }^{12 \%}$ and urge states to value local communities as a source of knowledge and practices that contribute to realizing sustainable development. ${ }^{130}$ The Rio Declaration alone also calls for judicial and administrative outlets as a means for resolving environmental conflicts. ${ }^{131}$ Collectively, these ten-

Christine Padoch eds., 1992) (advocating the inclusion of resulting costs such as erosion, floods, and species extinction in the calculation of forest destruction).

${ }^{124}$ See Forest Principles, supra note 59, at princ. 13(c) ("Incorporation of environmental costs and benefits into market forces and mechanisms, in order to achieve forest conservation and sustainable development, should be encouraged both domestically and internationally.").

125. Goodland, supra note 123, at 426. Goodland offers the example that "if a managed forest can yield 4 percent and is judged uneconomic in comparison with a discount rate of 6 percent for a project that is unsustainable ..., then the decision boils down to sustainable versus unsustainable use." $I d$. He continues: "If our policy is sustainable development, then we choose the sustainable course; the fact that it has a negative present value at an unsustainable discount rate is irrelevant." Id.

${ }^{126}$ Hoyt, supra note 26 , at 213.

127 Principle 5(a) states:

National forest policies should recognize and duly support the identity, culture and the rights of indigenous people, their communities and other communities... enabl[ing] them to have an economic stake in forest use, perform economic activities, and achieve and maintain cultural identity and social organization, as well as adequate levels of livelihood and well-being .... Forest Principles, supra note 59 , at princ. 5 (a).

${ }^{124}$ Rio Declaration, supra note 5, at princ. 10; Forest Principles, supra note 59, at princ. $2(c)$

12:1 See Rio Declaration, supra note 5, at princ. 22 (arguing that states should recognize and support the participation of local communities in environmental management); Forest Principles, supra note 59, at princ. 2(d) (requiring governments to promote the involvement of individuals and communities in forest planning)

1:311 Rio Declaration, supra note 5, at princ. 22; Forest Principles, supra note 59, at princ. 12(d).

131 Rio Declaration, supra note 5 , at princ. 10 
ets set the foundation for a relationship between the state and communities dependent on state-owned natural resources that are necessary for the implementation of localized forest management.

If anything, the Plan of Implementation, the most recent expression of sustainable development by the international community, features the most elegant and concerted support for community forestry yet. Among the nine actions specified to achieve sustainable development is to " $[r]$ ecognize and support indigenous and community-based forest management systems to ensure their full and effective participation in sustainable forest management." ${ }^{192}$ More generally, the Plan of Implementation presents overarching principles guiding sustainable development at the national level, including support for local management initiatives, ${ }^{133}$ access to policy information and programs, ${ }^{194}$ and enhanced participation of stakeholders and the broader public in the allocation of natural resources. ${ }^{195}$ In other words, community forestry fulfills the current international environmental agenda featuring “' $[\mathrm{g}]$ rassroots' empowerment" as a centerpiece. ${ }^{1.96}$

\section{Sustainable Development and Human Rights}

Sustainable development is unquestionably more than just a compromise between states over the current international environmental policy. Rather, the Rio Declaration places human beings, and not states, "at the centre of concerns for sustainable development."1.37 Moreover, the obligations of states detailed in the Rio Declaration focus on the relationship between states and their own people with respect to the environment. ${ }^{198}$ This signals a dimension of sustainable development unexplored to this point in its description. Sustainable development is not strictly an environmental goal of the international community but a constraint on state action in the form of rights held by communities recognized in the Rio Declaration and other instru-

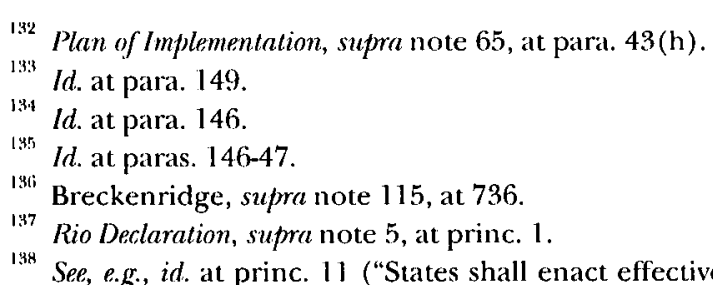
Environmental standards, management objectives and priorities should refle vironmental and developmental context to which they apply. Standards applied by some countries may be inappropriate and of unwarranted economic and social cost to other countries, in particular developing countries."). 
ments on sustainable development. It is these rights, which the international community has made a fundamental component of sustainable development, that arguably give shape to a "right to environment."

The role of human rights in sustainable development means that the Rio Declaration and the Forest Principles do more than endorse community forestry as a form of implementing sustainable development. By embracing the application of human rights in the struggle for environmental protection, they place local communities at the center of designs to implement sustainable development.

The role of local communities in protecting the environment reflects "something of a revolution in international environmental policy." "199 Previous attitudes in the international community advocated a hard-line conservationism, viewing local communities as a threat to the environment that should be excluded. ${ }^{140}$ Lee Breckenridge argues that this transformation of international environmental law took place due to a convergence of environmental and human rights perspectives to prevent the gross exploitation of natural resources by governments and private entities. ${ }^{141}$ As he conceives these two perspectives, their union is not a natural one.

Initial reactions to the growing problem of natural resource exploitation engendered competing positions between the two sides. The environmental approach sought international control of the environment in order to protect the international community from the global effects of domestic degradation. The human rights approach sought local control through secure property rights, as well as protection of the autonomy and self-determination of local communities from encroachment by either international control of their environment or its destruction. Breckenridge ponders that, "[p]erhaps because existing international law has seemed insufficiently effective, advocates for 'environmental' and 'human rights' causes' have reached out, in recent years, to form alliances and to make use of each other's legal rhetoric to gain additional leverage." ${ }^{1+2}$ Sustainable development is a direct by-product of this trend.

This Part examines the nature of a right to environment and the role of human rights in the effort to achieve sustainable development.

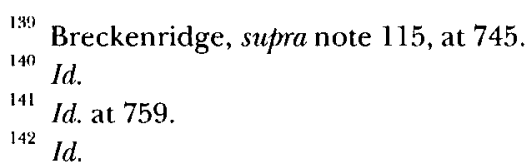


The discussion drives toward two basic conclusions. First, the concept of sustainable development defines a right to environment by invoking preexisting rights in an environmental context. Second, this human right to environment plays an indispensable role in achieving the implementation of sustainable development. The international community needs to move more decisively in the direction of recognizing a human right to environment if it is to establish a framework in which sustainable development can become a global reality.

Part II presented the argument that community forestry promotes the resource management and incentives necessary to realize the international agenda of sustainable development at the local level. This is not to say that the conduct of governments within their own borders conforms with international policy, even when the same governments have pronounced their commitment to the policy in question. Thus, the promise of community forestry falls far short of securing its own implementation in the developing nations that helped to forge the concept of sustainable development on a policy level and pledged to follow it on a practical level. To the contrary, the Pheapimex Concession shows that governments of developing states can, and often do, align with industry against sustainable use and local control of resources. ${ }^{143}$ Governments and industry are also the most influential determinants of resources in developing states.

The human right to environment empowers private parties to enforce the commitments of developing states to strive toward sustainable development. There is nothing radical about these assertions. While the debate over a right to environment continues, this Part identifies strong support among commentators for the existence of the human right, albeit in a strictly procedural form. According to these commentators, the right to environment is the right of participation in environmental matters. Such participation forces the input of local communities and other stakeholders in to an otherwise unilateral decision-making process by states and their favored constituents-a process that often results in disposing of natural resources in circumvention of the principles of sustainable development. This procedural right constitutes one component of the right to environment. However, this moderate position, regarding the right to environment strictly by these terms, strips the right of its potency and undermines its purpose by denying the crucial function of the right:

14.3 See supra notes 38-40 and accompanying text (positing reasons for why states defy sustainable resource management even in the face of alarming resource deple(ion). 
empowering local communities. It is thus integral for the right to environment to contain not only a procedural but also a substantive component furthering social, economic, and cultural rights as they relate to environmental matters. Only then does the procedural aspect of the right amount to anything more than a formality. Only then is the design for implementing sustainable development feasible and complete.

\section{A. The Obstacles to Realizing a Human Right to Environment}

The first statement of a human rights approach to environmental protection was a forceful one. The Declaration of the U.N. Conference on the Human Environment produced at Stockholm in 1972 (Stockholm Declaration) laid out as its first principle that " $[\mathrm{m}]$ an has the fundamental right to freedom, equality and adequate conditions of life, in an environment of a quality that permits a life of dignity and well-being."144 Despite such unequivocal language, there is strong reason to believe that the Stockholm Declaration and subsequent international instruments (most notably, the Rio Declaration) fell short of giving life to a substantive human right to environment. ${ }^{145}$

Among the evidence offered in support of this conclusion is that significant problems exist in defining the contents of a right to environment. ${ }^{146}$ Michael Anderson notes that in reply to the dilemma of

${ }^{144}$ Declaration of the U.N. Conference on the Human Environment, princ. 1, U.N. Doc. A/CONF.48/14 (1972) [hereinafter Stockholm Declaration], reprinted in 11 I.L.M. 1416, 1417.

i45 See P.W. BIRNie \& A.E. Boyle, InTERnational L.AW AND THE ENVIRONMENT 254-67 (2d ed. 2002) (discussing why international law has yet to embrace an independent right to environment). For an explanation of why the Slockholm Declaration. never gave rise to a right to environment, see ALEXANDRE KISS \& DINAH SHELTON, INTERNATIONAL ENVIRONMENTAL LAW 60-63 (2d ed. 2000); Louis B. Sohn, The Stockholm Declaration on the Human Environment, 14 HARV. INT'L L.J. 423, 455 (1973).

${ }^{146}$ For a complete discussion of the arguments offered against the existence of a substantive human right to environment and the issues facing any attempt to fashion one, see Michael R. Anderson, Human Rights Approaches to Environmental Protection: An Overview, in Human Rights ApPronches To Environmental Protection 1, 10-19 (Alan E. Boyle \& Michael R. Anderson eds., 1996); Alan Boyle, The Role of International Human Rights Law in the Protection of the Environment, in HUMAN RIGHTS APPROACHES TO EnVironmental Protection, supra, at 43, 48-57; Günther Handl, Human Rights and Protection of the Environment: A Mildly "Revisionist" View, in Human Rights, SustalNable DEVELOPMENT AND THE ENVIRONMENT, supra note 54, at 117, 129-32. Boyle sums up the core criticisms nicely in the following passage:

$[\mathrm{T}]$ he recognition of [a human right to environment] is neither necessary nor desirable.... [in light of] the difficulty of definition, the inefficiency of developing environmental standards in response to individual complaints, the 
how substantive environmental rights should be defined, "[r]eferences are made to a 'clean', 'healthy', 'decent', 'viable', 'satisfactory', 'ecologically balanced', or 'sustainable' environment. . . . But such definitions often do little definitional work, and end up begging the question [they seek to resolve]."147 It is possible that the ambiguity surrounding the right is inherent. Alan Boyle explains that any attempt to identify the qualitative aspects of environmental rights may suffer from cultural relativism. ${ }^{148}$ A strategy to avoid this problem focuses the definition of environmental rights on narrower concepts, such as health, that are more easily adapted to legal standards. According to Boyle, however, this solution proves self-defeating because the results "scarcely address[] environmental protection at all."149

Another argument against the existence of a substantive human right to environment is that it is disadvantageous. Günther Handl warns that a right to environment possesses a siren-like quality-it sounds admirable in theory, but this only serves to divert attention from its many disadvantages in practice. ${ }^{150}$ Among Handl's more biting criticisms are that the right is too simple to adequately address the complexity of environmental issues; it aims to cure mere symptoms without solving the structural causes of environmental degradation; it

\begin{abstract}
inappropriateness of human rights bodies for the task of supervising obligations of environmental protection, and the fundamentally anthropocentric character of viewing environmental issues through a human rights focus, entailing a form of "species chauvinism." Moreover, since the evolution of environmental protection within particular societies necessarily involves a complex balancing process and an ordering of socio-economic priorities, it is impossible to treat environmental rights as either inalienable or nonderogable.
\end{abstract}

Boyle, supra, at 49. For a presentation of the criticisms levied against a substantive right to environment and the counterarguments to them, see Rodriguez-Rivera, supra note 71 , at 29-37.

${ }_{147}$ Anderson, supra note 146 , at $10-11$.
Boyle, supra note 146 , at 50.
${ }_{14 !}$. Birnie and Boyle explain the problem in the following manner:

The strongest argument in favour of a qualitative interpretation [of a right to environment] is that other human rights are themselves dependent on adequate environmental quality, and cannot be realized without governmental action to protect the environment. This is doubtless true, but does not overcome the problems of implementation and definition which are the main obstacles to the development of environmental law along such lines.

Patricia W. BiRnie \& Alan E. BoIle, INTERnational LAW and THE ENVIRONMENT 197 (1st ed. 1992).

See Hand, supra note 146, at 142 (calling an environmental human right "little more than legal window-dressing" and advocating a more "realistic" approach that builds on existing international environmental structures toward a general recognition of "specific or well-defined environmental rights"). 
offers no assurances that the benefits of environmental preservation will inure to the disadvantaged groups for which it is designed; and, finally, it threatens both to attract the ire of developing nations and industry while crowding out other legal remedies better suited to environmental issues. ${ }^{151}$ Handl believes that these significant negatives militating against a substantive right to environment are largely ignored in public discourse of the issue because of the accepted relationship between preservation of the environment and promotion of human rights. ${ }^{152}$ Handl concedes that the relationship is "selfevident," but warns against conceptualizing environmental protection in terms of human rights as a result of the downsides he describes inherent to the approach. ${ }^{153}$

A final justification for the claim that there is no substantive human right to environment is the Rio Declaration itself. The Rio Declaration is not formally binding on the international community. ${ }^{154}$ Consequently, it does not entail a response to the formalistic objection that dogged the Stockholm Declaration's construction of the rightnamely, that a substantive right to environment "has not found express affirmation in any binding or effective international legal instrument."

Still, even the most adamant proponents of this criticism do not suggest that nonbinding instruments exercise no influence on the international order, ${ }^{156}$ The Rio Declaration can constitute a traditional source of international law ${ }^{157}$ giving rise to a right to environment if viewed as codifying existing state custom. Unanimous state support for the Rio Declaration at its conference and through the U.N. General Assembly is only the beginning of this inquiry. The claim that the Rio Declaration has the character of customary international law requires a showing that its principles reflect definitive state practice and opinio

${ }^{151}$ See id. at $137-39$ (criticizing a human right to environment). But see RodriguezRivera, supra note 71, at 31-32 (summarizing and rebutting Handl's arguments by asserting that Handl wrongly assumes that a human rights approach to environmental protection operates in isolation, rather than as part of an interdisciplinary approach, and that Handl's arguments merely attack the effectiveness of a human right to environment but do not question its existence).

${ }^{152}$ Handl, supra note 146 , at 119.

15: Id.

${ }^{154}$ U.N. CHARTER art. 10.

155. Handl, supra note 146, at 122.

156 See id. at 128 (noting the practical effects of nonbinding instruments).

157 See infra note 165 (setting forth the text of Article 38(1) of the Statute of the International Court of Justice, which lists the traditional sources of international law). 
juris, i.e., state belief that a principle is accepted as law. ${ }^{1: 8}$ While some commentators affix the label of customary international law to narrow areas addressed by the Rio Declaration, ${ }^{159}$ broader assertions, like the rise of a substantive right to environment from the Rio Declaration, are viewed as aspirational. ${ }^{\text {lii) }}$ To make this point, Howard Mann compares the Stockholm Declaration and the Rio Declaration. He states that only one principle set forth in the Stockholm Declaration has been widely thought to constitute international law and argues that the Rio Declaration is of "no higher legal status." An examination of the decade following the Earth Summit and the WSSD confirms this conclusion. ${ }^{162}$ In sum, the characterization of the Rio Declaration as customary international law is subject to compelling normative objections.

Finally, commentators have looked beyond traditional source doctrine of international law to support the existence of a right to environment. One prevalent argument asserts that the Rio Declaration qualifies as a statement of "soft law" that, in conjunction with other international documents of a similar vane, creates a right to environment. ${ }^{163}$ Soft law describes "international norms that contain a mixture of ethical and political values or economic claims in a form not traditionally regarded as a source of international law." ${ }^{164}$ By definition, soft law defies the standard articulation of sources of interna-

15 See RoSalyn Higgins, Problems and Process: InTERnational l.aW and How WE USE IT 18-19 (1994) (explaining the concept of opinio juris and discussing the problems associated with the relationship between practice and opinio juris). For a reference to the Rio Declaration as it fits within the context of customary law, see Howard Mann, Comment on the Paper by Philippe Sands, in Sustainable Development And INTERNATIONAL LAW, supra note 56, at 67, 69 n.9.

159. See, e.g., Boyle, supra note 58, at 68 (stating that "the Declaration is in part a restatement of existing customary law on transboundary matters"); Sands, supra note 69 , at 57 (noting that "[e]lements of [the Rio Declaration] reflect, at least in part, customary international law").

(ix) Mann, supra note 158 , at 69 .

liti $I d$.

${ }^{162}$ See supra notes 64-66 and accompanying text (reviewing the disappointing results of the Rio Declaration discussed at the WSSD).

${ }^{163}$ See Rodriguez-Rivera, supra note 71 , at 45 (explaining that a right to environment is recognized "[i]f the sources of international law are expanded to conform to the evolution of modern international law"); see also R.S. Pathak, The Human Rights System as a Conceptual Framework for Environmental Law, in ENVIRONMENTAL CHANGE AND INTERNATIONAL LAW 205, 238-39 (Edith Brown Weiss ed., 1992) (describing the role soft law plays in developing international environmental law).

${ }^{16 \text { in }}$ Jonathan Carlson, Hunger, Agricultural Trade Liberalization, and Soft International Latu: Addressing the Legal Dimensions of a Political Problem, 70 IOWA L. REV. 1187, 1200 (1985). 
tional law found in the Statute of the International Court of Justice. These sources express a positivist conception of international law by virtue of the fact that accepted law includes that which has received state consent or commitment. llii Thus, under this orthodoxy, if the Rio Declaration were understood as binding (or "hard law"), there would be a strong presumption that it constitutes international law because all participating states consented to be bound by its terms. ${ }^{117}$ Because the Rio Declaration is nonbinding, it is a less persuasive articulation of state consent. ${ }^{168}$ However, this concession is not equivalent to dismissing the Rio Declaration as evidence of state support, nor does it negate the ability of the Rio Declaration to foster legal norms. ${ }^{16 !}$ To what effect the Rio Declaration has created a right to environment depends upon whether its principles enjoy the authority of having received state consent and the expectation that states will take its content seriously. ${ }^{170}$

Handl stresses that this analysis presents high, strict standards not met in the case for a soft-law formulation of a substantive right to environment. He surveys international and domestic practice and legislation ${ }^{171}$ and concludes that " $[\mathrm{t}]$ he evidentiary basis that proponents of [a right to environment] rel[y] upon is simply too narrow or normatively too weak to lend itself to the major normative extrapolation that a human right to a healthy environment would undoubtedly repre-

${ }^{105}$ Article $38(1)$ of the Statute of the International Court of Justice instructs the court to apply:

(a) international conventions, whether general or particular, establishing rules expressly recognized by the contesting States;

(b) international custom, as evidence of a general practice accepted as law;

(c) the general principles of law recognized by civilized nations;

(d) ... judicial decisions and the teachings of the most highly qualified publicists of the various nations, as subsidiary means for the determination of rules of law.

Statute of the International Court of Justice, 1947 I.C.J. Acts \& Docs. 37, 46 (ser. D) No. 1, at art. 38(1); see also HIGGiNS, supra note 158, at 19 (examining the controversy surrounding practice, custom, and opinio juris).

${ }_{16 i}$ Rodrigue\%-Rivera, supra note 71 , at 38.

${ }^{167}$ For a description of the perceived differences "between norms (hard law) and non-norms (soft law)," see $i d$. at 41.

168 Id.

${ }^{169}$ Carlson, supra note 164, at 1202.

${ }^{170}$ See id. at 1202-03 (describing the "essential ingredient" of soft law as possessing the attributes of international consent and intention of state adherence to the expressed norm).

${ }^{171}$ See Handl, supra note 146, at 120-29 (reviewing various approaches to the right to a healthy environment as an existing or emerging human right). 
sent." ${ }^{172}$ In other words, the content embodied by a right to environment is not, by Handl's estimation, supported by the endorsement of specific state consent or practice.

The language of the Rio Declaration seems to admit as much. The rights terminology found in the Stockholm Declaration is noticeably absent from the analogous first principle in the Rio Declaration. ${ }^{173}$ The omission is even starker considering the Rio Declaration's unambiguous affirmation of a state's sovereign right to exploit its own resources. ${ }^{174}$ At the very least, this signals uncertainty over the idea and, at most, reveals the absence of international consensus.

\section{B. The Procedural Form of a Right to Environment}

\section{As a Response to the Skeptics}

An alternative formulation of a human right to environment that dodges the pitfalls described above is the view that the right is procedural in character as opposed to substantive. The message for states in the Rio Declaration - to provide open access to information, participation in decision-making, or judicial or administrative dispute resolution, and to give credence to the knowledge and practices of local communities ${ }^{175}$ - while not framed clearly in terms of rights, arguably amounts to a human right to democratic governance in the environmental context. ${ }^{17 i}$ Alan Boyle espouses this view, understanding that these rights are contingent upon the notion that sustainable development is not left solely in the hands of the state. ${ }^{177}$ Rather, the Rio Declaration applies "notions of civic participation in public affairs already reflected in existing civil and political rights" to matters of the

${ }^{172} I d$ at 128 .

17.4 Boyle, supra note 146, at 43. The principle states that "[h] uman beings are at the centre of concerns for sustainable development" and that "[ $t]$ hey are entitled to a healthy and productive life in harmony with nature." Rio Declaration, supra note 5, at princ. 1.

${ }^{174}$ Rio Declaration, supra note 5, at princ. 2.

175. See supra notes 128-31 and accompanying text (listing procedural mandates in the Rio Declaration and the Forest Principles).

${ }^{176 i}$ Though the Rio Declaration and the Forest Principles do not overtly establish individual or communal rights, their language, particularly that of the Rio Declaration, can support that conclusion. Principle 10 of the Rio Declaration, the central principle on the issue of a human right to environment, features mandatory language that each individual "shall" enjoy the benefits described in the principle. Rio Declaration, supra note 5 , at princ. 10 .

177 Boyle, supra note 146 , at 60. 
environment. $^{178}$ In other words, the existing participatory rights found in the Universal Declaration of Human Rights (UDHR), ${ }^{17 \%}$ the International Covenant on Civil and Political Rights $(I C C P R),{ }^{1 \times 0}$ and other international human rights documents enforce the notion that the participatory rights in the Rio Declaration are, in fact, rights. What their inclusion in the Rio Declaration adds, given their prior existence, is their unmistakable application in environmental matters. ${ }^{\mid 81}$

This alone is significant. The rights to democratic participation in both the $U D H R$ and the ICCPR, as classically defined, state a general right to contribute to the composition of government-election of representatives being the foremost benefit they secure. The Rio Declaration arguably broadens this right to apply in cases when the government enters into contracts involving state-owned resources, thus creating a much stronger and more immediate form of public participation for those most affected by these decisions. Consequently, local communities need not wait for the next election cycle-and the attendant glut of other issues that compete for attention-to voice displeasure over harm to their environment. The opinion of local communities lends weight and credibility to the initial government decision empowering these communities to a degree not specifically envisioned under the designs of either the UDHR or the ICCPR.

Boyle concludes from his analysis that " $[\mathrm{p}]$ ublic participation ... is thus a central element in sustainable development." ${ }^{\text {82 }}$ His version of sustainable development establishes a role for those most affected by instituted changes to the environment in determining the balance

178 Id.; see also BIRNIE \& BOYLE, supra note 145, at 261 ("The narrowest but strongest argument for a human right to the environment focuses not on environmental quality, but on procedural rights, including access to environmental information, access to justice, and participation in environmental decision-making."). Handl warns against deriving environmental rights from existing human rights. He argues that "the existence of an established human right that is conceptually related, perhaps in some way even logically antecedent, to the claimed environmental entitement, cannot be invoked dispositively to establish the latter's international normativity as 'derived from' or 'subsumed under' the former's." Handl, supra note 146, at 126. Note that this attack, as stated, is not levied against a procedural right to environment since existing procedural rights are not used to "derive" environmental rights. Boyle merely applies procedural rights to the environmental context. Handl even endorses such rights, albeit on a regional (as opposed to global) level. Id. at 139-41.

${ }^{17 !}$ Universal Declaration of Human Righis, G.A. Res. 217(A) (III), U.N. GAOR, at arts. 19, 21, U.N. Doc. A/810 (1948) [hereinafter UDHR].

(18) International Covenant on Civil and Political Rights, G.A. Res. 2200(A) (XXI), U.N. GAOR, at arts. 19, 25, U.N. Doc. A/6316 (1966), reprinted in 6 I.L.M. 360, 366-67.

${ }^{181}$ Boyle, supra note 146 , at 61 .

Id. at 64 
of environmental, social, and economic interest with respect to a state's natural resources. ${ }^{18.1}$ Additionally, it preserves flexibility by defining sustainable development on a national level, taking into account the differences between states that shape the look of environmental protection. ${ }^{144}$ These benefits do not exist for local communities under an international regime that maintains a substantive human right for the protection of the environment. ${ }^{\text {Is: }}$

Finally, procedural rights not only comport with the Rio Declaration but also address the "greatest challenge for both human rights standards and environmental regulation": the problem of enforcement. ${ }^{186}$ It is said that a practical remedy is "worth a thousand pious pronouncements." 187 The extensive scope of environmental regulation that is already in place begs the question of what else a substantive human right to environment could achieve. Boyle suggests that the novel approach to environmental law shows no indication of contributing anything but redundancy to a fledging system. ${ }^{188}$ Typically, human rights are valuable tools of the international community because they have direct effects on domestic policies. ${ }^{\text {IN! }}$ In this area, Boyle observes that international encroachment already has laid to waste domestic sovereignty. ${ }^{196}$ For those states that remain defiant, the addition of human rights will not spark them to rethink their positions.

$183 \mathrm{lll}$.

IS. $\mathrm{ld}$.

185) See id. "What constitutes sustainable development and an acceptable environment is in the end a matter for each society to determine according to its own values and choices....").

${ }^{181 ;}$ Anderson, supma note 146, at 19; see also Andrew Harding, Practical Human Rights, NGOs and the Environment in Malaysia, in HUMAN Rights Appronches to Environmental Protection, supra note 146, at 227, 228 (discussing envirommental legislation and the "inadequacy of enforcement" in Malaysia).

${ }^{187}$ Harding, supra note 186, at 229.

${ }^{148}$ See Boyle, supra note 146, at 53 ("While it would have undoubted rhetorical force, such a right [to a 'decent environment'] in international law may in reality be largely redundant.").

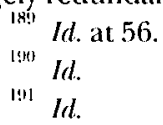




\section{A Procedural Right to Environment in Action: Why It Is Inadequate}

A strictly procedural conception of a human right to environment steers the resolution of environmental matters in a political direction as opposed to a legal one. Under this view, the interests of local communities dependent on natural resources-to which the successful implementation of sustainable development is intimately connected-are given adequate voice through democratic decision making with regard to such natural resources. The implementation of a political framework alone is deficient. It does not sufficiently empower environmentally reliant communities and thus does not promote sustainable development. Merely having a place at the negotiating table does not mean that anyone is listening to these communities. Their opinions are hollow so long as there is a lack of authority behind them. And that is only dependably rectified by arming reliant communities with substantive legal rights.

The features of a community forest can range across a wide spectrum. $^{192}$ There are, however, certain commonalities, of which one is crucial for our purposes. The creation of a community forest management system requires an agreement between local communities, as the users of the forest, and the government, as the landowner. ${ }^{113}$ As the example of the Pheapimex Concession shows, states have little or no incentive to enter into an agreement formalizing a joint ownership of the forest. ${ }^{194}$

${ }^{192}$ The authoritative source on the subject in Cambodia is the Community FORESTRY GUIDELINES, supra note 106. Concern Worldwide, an NGO operating a Community Forestry Program and a leader in the effort to establish community forests in Cambodia, attempts to follow the procedures described in the Community Forestry Guidelines in its projects. Telephone Interview with Danny Harvey, Advisor, Community Forestry Program, Concem Worldwide (July 26, 2001). Broadly, there are three basic steps en route to establishing a community forest: (1) local- and provincial-level planning including collecting information about the forest, its resources, and local community dependence on them, determining how the local villages organize themselves, educating villagers on the concept of community forestry, and beginning to provide technical training; (2) preparation of an application by the communities for submission to the appropriate authorities; and (3) formalization of the classification through a community forest agreement defining the location of the community forest, its duration, and the local communities' rights and obligations with respect to it. COMmUNITY FORESTRY GuIDELINES, supra note 106, at 4-15, 20-21.

193 Romm, supra note 108 , at 228 .

$1: 4$ See supra Part I (demonstrating that financial benefits from failing to prevent deforestation may outweigh the desires and needs of local populations in decisions of resource allocation by impoverished states). 
Formally and informally, Cambodia consented to abide by the doctrine of sustainable development. Cambodia attended the Earth Summit, proclaiming the Rio Declaration. ${ }^{195}$ In 1955 , it became a member of the U.N. General Assembly, ${ }^{196}$ which later adopted the Rio Declaration without a vote. ${ }^{197}$ The Cambodia Human Development Report 1999: Village Economy and Development, released by the Ministry of Planning, ${ }^{1,4}$ echoes the fundamental principle of sustainable development that local communities must have a right to participate in decisions affecting their economic futures. ${ }^{169}$ Cambodia has passed many laws that integrate the components of sustainable development into domestic law. ${ }^{201}$ Most recently, it was an active participant in the WSSD and its preparation ${ }^{201}$ and gave its support to the Plan of Implementation. ${ }^{202}$

195 Rio Declaration, supra note 5 , at pmbl.

${ }^{1966}$ List of Member Stales, United Nations, at http:\%/www.un.org/Overview/ unmember.html (last modified Apr. 24, 2003).

$1: 7$ U.N. Voting Records, Report of the United Nations Conference on Environment and Development: Resolution Adopled by the General Assembly, U.N. Doc. A/RES/47/190 (1992), available at http://unbisnet.un.org/webpac-1.2/index.html.

$19 \%$ Cambodia Human DEvelopment REPORT 1999, süpra note 79.

19!. See idl. at 21-22 ("For true development to take place in villages, the ultimate stakeholders (viz., communities, villages and villagers) should be fully involved in the process of their economic development and should, indeed, take on a larger advocacy role with respect to central and provincial governments, international donors, and the private sector.").

2(16) See, e.g., Cambodian Law on Environmental Protection and Natural Resource Management ch. 7, arts. 16-18 (encouraging public participation by providing for access to information on environmental protection and natural resource management), available $a$ http://law.nus.edu.sg/apcel/dbase/cambodia/primary/caaenv.html; $i d$. at ch. 3, art. 6 (requiring completion of an environmental impact assessment on projects, both private and public, for review by the Ministry of Environment before the project is considered by the Royal Government of Cambodia); Cambodian Draft Forestry Law ch. 14, art. 74 (calling for a subsequent subdecree on using state forestland to plant trees, taking into account the potential social and environmental impact of the species).

REPORT OF THE WORLd SUMmIT ON SUSTAINABLE DEVELOPMENT at 74, U.N. Doc. A/CONF.199/20*, U.N. Sales No. E.03.II.A.1 (2002) [hereinafter REPORT ON SUSTAINABI.E DEVELOPMENT], available at http://www.johannesburgsummit.org/html/ documents/summit_docs/131302_wssd_report_reissued.pdf. Cambodia also hosted a regional platform on sustainable development in preparation for the WSSD. See UNTTED NATIONS, ECONOMIC AND SOCIAL COUNCIL, TASK FORCE FOR THE. Preparation of WSSD in asia and the Pacific, Phinom Penh Regional Platform on Sustainable DeVloopment for ASIA AND THE PACIFIC at 1 (2001) (discussing the importance of Asia and the Pacific in promoting sustainable development), available at http://www.unescap.org/enrd/environment/Activities/hrm_wssd/ENR_HRM_WSSD _Platform.doc.

202 REPORT ON SUSTAINABI.E DEVELOPMENT, supra note 201, at 139. 
Some measures taken by the Cambodian government support the conclusion that it made an effort to comply with international mandate in granting the Pheapimex Concession. For example, representatives of the Ministry of Environment were dispatched to consider the environmental impact of the proposed project on the 5000 hectares of forest where Pheapimex was authorized to begin work. ${ }^{203}$ This arguably fulfills the state's obligation to perform an environmental impact assessment under the Rio Declaration ${ }^{204}$ and the Forest Principles. ${ }^{20.5}$ It is worth mentioning, however, that both inspectors from the Ministry of Environment submitted recommendations that the project not proceed due to potential environmental harm. ${ }^{206}$ Also, steps were taken to involve the local community in the form of a meeting between representatives of the local villages and members of the provincial government with authority over the matter. Participation of the local population held little significance at best, since the government's overtures came more than a full year after the Pheapimex Concession was executed committing the forest to Pheapimex. ${ }^{207}$ Therefore, it can hardly be said that the local villages contributed to the decisionmaking process concerning the concession. Overlooking the timing of events, state officials retained the opportunity to reconcile local concerns with the Pheapimex Concession. The Secretary of MAFF remarked that "if any problems arise with local people ... the company should cooperate with the government to discuss the problem." ${ }^{208}$ Despite emphatic local opposition expressed to various levels of government on numerous occasions, ${ }^{209}$ the Secretary of MAFF ne-

203 Author's Notes from Meeting in Pursat (July 11, 2001) (on file with author). The involvement of officials from the Ministry of Environment came at the expense of the LAC Land Unit. Unlike the general survey performed years earlier by the Chief of Pursat Province, Letter from MAFF Chief, supra note 17, the more recent study focused on the area of concern for the Ansa Chambak and Kbal Trach communes as an attempt to strengthen their argument for a community forest. Still, to the credit of the Ministry of Environment, its officials were permitted to go.

${ }_{214}$ Rio Declaration, supra note 5 , at princ. 17.

205. Forest Principles, supra note 59, at princ. 8(h).

${ }^{2065}$ Author's Notes from Meeting in Pursat, supra note 203.

207 The Pheapimex Concession was signed in January 2000 while the meeting between the villagers of the Ansa Chambak commune and the provincial administration did not occur until March 2001. See supra notes 6-7, 22, 32 and accompanying text (recounting the chronology of these events).

208 Letter from MAFF Secretary of State, supra note 15 , at 1 .

${ }^{209}$ See supra notes 22-34 and accompanying text (describing community reliance on forestland and opposition to the Pheapimex Concession). 
glected to intervene. ${ }^{210}$ Finally, local communities could seek redress in the Cambodian court system as provided for in the Rio Declarationsecuring "[e]ffective access to judicial and administrative proceedings." 211 The legality of the Pheapimex Concession under Cambodian law could be questioned in several regards. ${ }^{212}$ However, there is a severe lack of confidence in Cambodia's court system, particularly in conflicts featuring parties of disparate power or wealth. ${ }^{218}$ The weak judicial branch is prone to favoritism and corruption in such circumstances, undermining the reliability of the courts to deliver equitable remedies. $^{214}$ Given Pheapimex's financial position, its political connections, its position as a landholder of a considerable portion of Cambodia, and its history of demonstrating a penchant for "might makes right" tactics, ${ }^{215}$ little hope exists for a legal solution. In sum, the Pheapimex Concession illuminates the deficiencies of a procedural right to environment that fails to address the lack of power held by local communities, which the procedural right is intended to protect. The procedural protections are reduced to mere formalities.

Government behavior suggests that without a formal connection between the forest and the surrounding communities, local input is easily ignored. The Secretary of MAFF has asserted that no connection exists; ${ }^{21 i}$ and, of course, in a traditional ownership sense, he is correct. Consequently, it may be argued that a procedural conception

210) Instead, the Secretary of MAFF authorized Pheapimex to proceed according to the Pheapimex Concession. Letter from MAFF Secretary of State, supra note 15, at 1.

"11 Rio Declaralion, supra note 5, at princ. 10.

212 Challenges to the Pheapimex Concession could take a variety of approaches under Cambodian law in effect at the time. Its terms arguably violate the rights of local inhabitants established under the Immovable Property Bill. See Law on the Land pt. III (Oct. 13, 1992) (Cambodia) (creating rights of usufruct, possession rights, and rights to use and to stay), atoilable at http://www.bigpond.com.kh/Council_of_Jurists/ Foncier/fon(001 g.htm. Alternatively, the Cambodian government's authority to enter into the agreement is arguably undercut by procedural requirements concerning concessions in the law on Environmental Protection and Natural Resource Management. See Environmental Protection and Natural Resource Management ch. III (Dec. 24, 1996) (Cambodia) (requiring an environmental impact assessment for projects submitted to the government for approval), available at http://www.bigpond.com.kh/ Council_of_Jurists/Envirmnt/env00lg.htm.

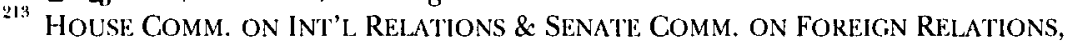
107 rh Conc., Country Rleports on Human Rights Practices for 2001, at 834-35 (Comm. Print 2002).

214 Id.

215 See Part I, and particularly note 10 and accompanying text, for a detailed discussion of Pheapimex's abuses in conducting its agro-industrial projects and in exercising influence as a force in Cambodian politics.

${ }^{216}$ Letter from MAFF Secretary of State, supra note 15 , at 1. 
of a human right to environment has limited potential to impact environmental exploitation within developing nations without also imbuing the local communities that utilize such procedures with substantive leverage in the eyes of the state.

One method of lending weight to the position of communities reliant on the local environment is political, through international NGOs. Among the advantages of the procedural interpretation of environmental rights, Boyle lists the increased "rights of intervention" provided to $\mathrm{NGOs}^{217}$ and, consequently, their augmented importance. David Wirth takes this issue up in extensive detail arguing that "a partnership model of advocacy can be an effective tool for ... public interest organizations to achieve responsible environmental policies in developing nations." $\mathrm{He}$ explains that the international organization acts as a conduit to communicate local concerns to the international community. ${ }^{219}$ This, in turn, often leads to international intervention in developing states' affairs in the interest of furthering the international agenda to support local communities. ${ }^{220}$ In fundamental terms, the partnership model achieves a coalescence of "legitimacy" (provided by directly affected communities) and "leverage" (provided by the international community through NGOs) to advance a shared agenda. $^{221}$

${ }^{217}$ Boyle, supra note 146 , at 62.

${ }^{21 *}$ David A. Wirth, Legitimacy, Accountability, and Partnership: A Model for Adyocacy on Third World Environmental Issues, 100 YALE L.J. 2645, 2649 (1991). Ross Daniels, a member of Amnesty International's International Executive Committee responsible for Asia, acknowledges the role of NGOs in promoting sustainable development practices and urges the further use of international human rights in that effort.

NGOs engaged in challenging the negative human or environmental impact of various models of economic development should fully utilise the language, framework and mechanisms of human rights protection in their advocacy and campaigning work. They play a front-line role as human rights monitors and defenders in the course of their struggle for alternative, people-oriented, sustainable development.

Ross Daniels, APEC: Human Rights and Development, Speech at the Manila People's Forum on Asia Pacific Economic Cooperation 12 (Nov. 1996), available at http://web.amnesty.org/aidoc/aidoc_pdf.nsf/index/IOR300061996ENGLISH/\$File/ IOR3000696.pdf.

21! Wirth, supra note 218 , at 2658.

2201 I.

221 $I d$. at 2651. The partnership process also has potential to enact changes in international law-specifically, human rights law-as according to ideational theorists. Ideational theory posits that the source of human rights commitments lies with influential ideas capable of shaping the interests of state and non-state actors. Lawrence $\mathbf{R}$. Helfer, Overlegalizing Human Rights: International Relations Theory and the Commonwealth Caribbean Backlash Against Human Rights Regimes, 102 ColuM. L. REV. 1832, 1842 
This paradigm has immense potential for application to Cambodia because it relies on foreign aid for nearly half of its operating budget. $^{222}$ Cambodia's past pledges to international donors to stamp out the illegal timber trade validates this point. In spite of promises, human rights and other organizations suspected a conspiracy among government and military personnel to continue felling trees for the timber market. ${ }^{229}$ These fears contributed to a decision by the World Bank to suspend aid, which elicited swift action by Cambodia's government. $^{224}$

The danger of depending on international NGOs to supply environmentally reliant communities with the influence that makes procedural rights effective is two-fold. Most obviously, it undermines the self-reliance of the rights-holders. It is unrealistic to think that the rural villagers of Cambodia, or elsewhere among developing nations, can independently exercise and protect their human rights. However, to promote dependence on NGOs as part of the system for enforcing human rights is hardly ideal and prompts questions as to the sustainability of such a system. In addition, the degree of dependence on NGOs threatens to create inherent inequality in the enforcement of human rights. A village's right to substantively participate in the decision-making process over the future of the local environment becomes linked to the accessibility of the NGO community, organizations' ability to advocate on behalf of the village, and the availability of NGO resources to pursue a beneficial resolution.

(2002). Changes in human rights law follow a "spiral model" according to which "transnational networks [and] domestic compliance constituencies create 'boomerang' patterns of influence on 'vulnerable' states by pressuring government officials "'from above" and "from below."” Id. at 1845-46 (citations omitted). Extrapolating further, from changes in a limited number of states there occurs a cascading effect in which "collections of norm-affirming events . . lead states rapidly to conform their conduct to international standards and implement those standards in their domestic legal systems." Id. at 1846; see alsọ Harold Hongju Koh, Why Do Nations Obey International Law?, 106 YALE L.J. 2599, 2655-56 (1997) (explaining the process of intervention and compliance in the transnational legal process); Thomas Risse \& Kathryn Sikkink, The Socialization of International Human. Rights Norms into Domestic Practices: Introduction, in THE POWER OF HUMAN RIGHTS: INTERNATIONAL NORMS AND DOMESTIC CHANGE 1, 5-6 (Thomas Risse et al. eds., 1999) (arguing that advocacy networks help bring about "sustainable domestic change in the human rights area").

${ }^{222}$ Suvendrini Kakuchi, Development-Cambodia: Hun Sen Gets Aid-And New Chance, INTER PrESS SERvice, Feb. 26, 1999, LEXIS, InPres File. For 1999, the figure pledged to Cambodia by a group of twenty-three international donors, including sixteen governments, was $\$ 470$ million. Id.

${ }^{223} \mathrm{Id}$.

${ }^{224}$ Cambodia Vous to "Ty Its Best" to Saze Forests, Agence France Presse, Feb. 25, 1999, I.EXIS, AFP File. 
Finally, it cannot be forgotten that the ultimate source of authority in Wirth's partnership model is not the NGOs but the international community-particularly states and other donors supplying aid. As a practical matter, these entities cannot monitor the world's commitment to sustainable development. Therefore, adopting a framework with a political mechanism for the enforcement of rights means that only those victimized by the most calamitous exploitations of the environment or by the most egregious governmental violators can expect to obtain redress through the human rights system. Those affected by the illegal timber trade that ravaged Cambodia's forests eventually received relief at the urgings of the international community. ${ }^{225}$ But what about those affected by smaller scale but equally destructive activities or, in the case of the Pheapimex Concession, a project that unfolds gradually, muting its effects? The entire sustainable development enforcement framework based on procedural rights alone seems to suffer from a potential for inherent inequality.

\section{A Substantive Right to Environment}

\section{Theoretical Foundations and Principle Content}

Procedural rights should constitute the beginning of an enforcement paradigm for sustainable development, not its entirety. While Boyle is correct to emphasize a procedural approach to achieving sustainable development, a substantive right to environment remains necessary. It extends the procedure to the international forum and thereby grants reliable effect to the procedural aspect of the right. In a discussion of human rights, Rosalyn Higgins, a judge on the International Court of Justice (ICJ), exclaims that "it is to his own government that the individual will look for his most basic needs . . . [and] it is from his own government that an individual often most needs protection." Higgins's words could not ring more true in the context of environmental rights, as they perfectly underscore the reason why the international community must recognize a substantive right to environment.

The Rio Declaration declares from the outset that "[h]uman beings are at the centre of concerns for sustainable development." ${ }^{227}$ This

${ }^{225,5}$ See supra notes 223-24 and accompanying text (describing international efforts to pressure the Cambodian government into curbing deforestation).

${ }^{220}$ HICGINS, supra note 158 , at 95.

${ }_{227}$ Rio Deslaration, supra note 5, at princ. 1 (emphasis added). 
statement is significant because of the parallels it makes with international human rights. International law underwent a transformation in the area of human rights from governing the relations between states to taking for its subject "the dignity and worth of the human person." International human rights law recognizes that the individual possesses rights "simply by virtue of being a human person."22: Consequently, state sovereignty protected by the Charter of the United Nations $^{240}$ does not permit a state to infringe upon these rights. ${ }^{2.31}$ This limitation on state authority is enforced by venues beyond the state with jurisdiction over human rights infractions. ${ }^{232}$ Communities reliant on the local environment must have the ability to seek redress in an international forum for activities contrary to the notion of sustainable development just as they could for violations of other human rights.

The argument for a substantive right to environment is much like its procedural counterpart. To recall, the procedural rights expressed in the Rio Declaration are neither unique to the Rio Declaration nor elevated to the status of rights through their appearance in the Rio Declaration. Instead, the Rio Declaration merely confirms the application of preexisting rights to the environmental context. It can be said that the Rio Declaration serves an identical function with regard to substantive human rights, especially in the economic, social, and cultural spheres.

As previously discussed, the Rio Declaration attracted support amidst growing concerns for the burdens that poor individuals and nations shoulder as a result of environmental degradation. ${ }^{233}$ The

${ }^{22 \times}$ UDHR, supra note 179 , at pmbl. (emphasis added).

22: HicGiNs, supra note 158 , at 96.

${ }^{230}$ See U.N. CHARTER art. 2, para. 7 ("Nothing contained in the present Charter shall authorize the United Nations to intervene in matters which are essentially within the domestic jurisdiction of any State ....").

${ }^{231}$ Higgins explains that international human rights are unique among the principles of international law in that they take for their subject the individual as opposed to the state. Consequently, the obligations spelled out by international human rights law flow directly to the individual and "cannot be given or withdrawn at will by any domestic legal system." HigGins, supra note 158, at 95-96.

${ }^{292}$ See Pathak, supra note 163, at 215 ("With the adoption of the United Nations Charter in 1945, the philosophy of human rights passed into the jurisprudence of international law.... [I]ndividuals gained rights under international law and, to some degree, the means for vindicating those rights in the international plane...."); see also infra note 283 (listing a variety of international fora).

${ }^{23: 3}$ See supra notes $76-98$ and accompanying text (describing the connection between poverty and environmental harm and the international responses embedded in the Rio Declaration and the Plan of Implementation). 
UDHR and the International Covenant on Economic, Social and Cultural Rights (ICESCR) contain fundamental protections implicated in the relationship between poverty and environmental harm. Included are the right to free development of one's personality and maintenance of one's dignity in economic, social, and cultural terms, ${ }^{2,34}$ the rights to a standard of living and environment adequate for one's health and well-being, ${ }^{235}$ and the rights to cultural life and to benefit from scientific progress and its application. ${ }^{236}$ By affirming the human rights approach to environmental protection-and more specifically, by giving mention to many of these preexisting rights-the Rio Declaration reveals an awareness among the international community of the rela-

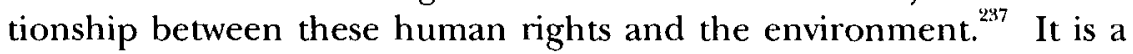
relationship with a reciprocal component. In one direction, these human rights play a vital role in the realization of environmental protection through sustainable development. In the other direction, environmental preservation is an essential characteristic of the fulfillment of other human rights. R.S. Pathak explains:

[T] he protection and improvement of man's environment arise directly out of a vital need to protect human life, to assure its quality and condition, to ensure the prerequisites indispensable to safeguarding human dignity and human worth and the development of the human personality, and to create an ethos promoting individual and collective welfare in all the dimensions of human existence.

That a substantive right to environment makes critical contributions to the fulfillment of economic, social, and cultural rights, especially in developing states, and the success of sustainable development, is the strongest argument for its existence.

It has already been conceded that the Rio Declaration, on its face, is more sedate in asserting a right to environment by comparison with the Stockholm Declaration of two decades earlier. Along the same lines,

${ }^{234}$ Intemational Covenant on Ecomomic, Social and Cultural Rights art. 1 [hereinafter ICESCR], http://www.unhchr.ch/html/menu3/b/a_cescr.htm; UDHR, supra note 179, at art. 22.

ICESCR, supra note 234, at arts. 11-12; UDHR, supra note 179, at art. 25.

236 ICESCR, supra note 234 , at art. 15 . For a more expansive, but arguably not exhaustive, list of international human rights that imply a right to the environment, see Rodriguez-Rivera, supra note 71 , at 22-23.

237 See Fatma-Zohra Ksentini, Human Rights, Environment and Development, in UNEP'S NEW WAY FORWARD: ENVIRONMENTAL LAW AND SUSTAINABLE DEVELOPMENT, supra note 77, at 95, 96 ("The relationship between human rights and the environment is widely recognised.").

Patsak, supra note 163, at 209. 
the Rio Declaration carefully delineates what states "shall" and "should" do throughout its principles. The more advisory term of "should" is reserved for the principles that give shape to a substantive right: achieving a higher quality of life, ${ }^{23 ! 3}$ strengthening efficient use of the environment through technology, ${ }^{240}$ promoting economic growth through environmentally sound trade, ${ }^{241}$ discouraging pollution that poses environmental and health risks, ${ }^{242}$ internalizing environmental costs, ${ }^{243}$ and mobilizing the youngest generation to implement and respect the idea of sustainable development. ${ }^{244}$ In sum, references to economic, social, and cultural rights in the Rio Declaration are couched in less forceful terms than procedural rights, which states "shall" provide.

It could be inferred from this correlation between the two types of rights and the two types of emphasis that a substantive right to environment is more aspiration than law. However, arriving at this conclusion ignores the differences among the types of rights themselves. Procedural rights impose clear, enforceable obligations on states. Economic, social, and cultural rights are not enforced with the same rigidity. ${ }^{245}$ Primarily, they are rights that the individual is expected to assert through her own efforts. ${ }^{24 i}$ States in this case must "respect the

239 Rio Declaration, supra note 5 , at princ. 8.

240 . at princ. 9.

241 Id. at princ. 12.

242 Id. at princ. 14.

243 ld. at princ. 16

244. Id. at princ. 21

245 See Asbjørn Eide, Article 25, in THE UNIVERSAL DECLARATION OF Human RIGHTS: A COMMENTARY 385, 386 (Asbjørn Eide et al. eds., 1992) (observing that human rights in general "do not necessarily constitute rights as understood in positive law").

246 This is the case for traditional economic, social, and cultural rights expressed in the UDHR and the ICESCR. See id. at 387 (explaining that the United Nations expects individuals to "ensure the satisfaction" of their needs). These rights are termed "second generation human rights." Pathak, supra note 163, at 215-16. Since the right to environment reflects an extension of second-generation human rights to the environmental context, its realization is also predicated on a combination of individual and state behavior. See Maggio \& Lynch, supra note 55, at pt. V (summarizing Higgins's characterizations of international human rights). By contrast, though, the right to environment takes this concept a step further: "'[It] can be realized only through the concerted efforts of all the actors on the social scene: the individual, the State, public and private bodies and the international community." Stephen P. Marks, Emerging Human Rights: A New Generation for the 1980s?, 33 RUTGERS L. REV. 435, 441 (1981) (quoting Karel Vasak's inaugural lecture to the Tenth Study Session of the International Institute of Human Rights in July 1979). Rights sharing this characteristic represent an innovation in human rights thinking that moves beyond second- 
freedom of the individuals to take the necessary actions and use the necessary resources. ${ }^{247}$ Only on a secondary level do states bear an obligation to actively protect these rights from encroachment or ensure their fulfillment by satisfying the basic needs of the individual. ${ }^{248}$ Even then, the obligation of states to take affirmative measures remains flexible to "accord[] with the organization and resources of each State."24: Consequently, for the Rio Declaration to set forth that states "shall," for example, provide a higher quality of life for all people misconstrues the nature of economic, social, and cultural rights. Achieving an adequate quality of life remains largely the responsibility of the individual. International law on the subject is first and foremost concerned with preventing states from inhibiting progress toward that goal.

Economic, social, and cultural rights have not been held historically in the same regard as civil and political rights. ${ }^{254}$ Thus, it may be the case that any reluctance to note their presence in a right to environment fashioned by the Rio Declaration, together with the attempt to recognize the procedural aspects of the right through the same instrument, is somehow a product of the differing status between the categories of rights. However, this artificial separation of civil and political rights from economic, social, and cultural rights defies the express and intended message of the $U D H R^{251}$ More recently, it was renounced by the international community at the World Conference on Human Rights in Vienna. ${ }^{252}$ The conference declared that "[a]ll hu-

generation rights. Consequently, the right to environment, among other recently formed rights, are donned "third generation [human] rights." Maggio \& Lynch, supra note 55 , at pt. V.

${ }^{247}$ Eide, supra note 245 , at 387.

${ }^{248}$ Id. at 387-89 ("State obligations consist, at a secondary level, of the protection of the freedom of action and the use of resources against other, more assertive or aggressive subjects ....").

${ }^{249}$ UDHR, supra note 179, at art. 22; see JOHANNES MORSINK, THE UNIVERSAL DECLARATION OF HUMAN RIGHTS 193-94 (1999) (indicating that the language of Article 22 of the UDHR considering the "resources of each State" was intended by the drafters to give context in the application of its terms to supply "adequate food and housing," and not to suggest that "these rights are less real").

250 See Eide, supra note 245, at 322 (relating the historical sources of social rights).

251 See UDHR, supra note 179, at art. 22 ("Everyone . . is entitled to realization . . of the economic, social, and cultural rights indispensable for his dignity and the free development of his personality.").

${ }_{252}$ World Conference on Human Rights: Report of the Secretary-General, U.N. GAOR, pt. III, § 5, U.N. Doc. A/CONF.157/24 (1993). 
man rights are universal, indivisible and interdependent and interrelated." "2:5

\section{Revisiting the Critics}

The foregoing discussion setting forth the fundamental grounds of a substantive right to environment within the framework of existing economic, social, and cultural rights draws considerable criticism as already examined. Part III.A raised questions of a theoretical and practical nature concerning a substantive right to environment in and of itself, as well as questions about its legitimacy within the international legal ethos. Having tested the mettle of the substantive right to environment laid out in the previous section, it is crucial to revisit these points of issue.

Chief among the criticisms described in Part III.A is Handl's contention that there is simply insufficient support for a right to environment. $^{254}$ To briefly review these objections, Handl first cites an absence of hard law establishing a right to environment. Thereafter, he depicts soft law expressions of the right to environment, including the Rio Declaration, as lacking the authority of having received state consent and the expectation of adherence. Finally, he argues that these essential ingredients of consent and expected adherence cannot be imported from existing human rights based on the interrelation between such rights and the environment.

There are several responses to Handl's conclusion that international law does not include a substantive right to environment. First, commentators take exception to Handl's evidentiary argument by referencing the literally thousands of instruments found on the international, regional, and domestic levels that promote a substantive right to environment. ${ }^{25.5}$ Each example brings greater credence to the assertion that "international human rights instruments lag behind current international attitudes."

Second, Handl possibly misconstrues the argument that a substantive right to environment exists by virtue of its relationship with existing human rights. Handl claims that advocates of this position unjus-

253 Id

${ }^{254}$ See supra notes 150-53 and accompanying text (detailing Handl's objections to what he perceives to be a vague notion of environmental human rights).

${ }_{255}$ See, e.g., Rodriguez-Rivera, supra note 71 , at $44-45$ (" $[\mathrm{T}]$ here are many instruments that serve as unmitigated sources for the recognition of the human right to environment in the international legal order:").

${ }_{2: 56}$ Maggio \& Lynch, supra note 55, at pt. I. 
tifiably "derive" a right to environment from the corpus of international human rights. ${ }^{257}$ In other words, Handl attacks the assertion of a "different" right on the ground that it closely affects an existing entitlement. ${ }^{258}$ The problem is a lack of state consent for the newly fashioned right. However, Handl's point becomes moot when the asserted right contributes to the existing right in terms of context and not content. ${ }^{259}$ In other words, application of economic, social, and cultural rights to the new context of environmental affairs is not equivalent to deriving a new right with unique content. The latter construction of a substantive right to environment, which Handl rightfully renounces, imposes new obligations on states without their consent. Alternatively, the former construction reflects an enunciation of rights already supported by states as part of international law. The Rio Declaration entails an international response to concerns over the linkage between poverty and the environment, ${ }^{2(i)}$ plainly draws on the fundamental principles of the UDHR and the ICESCR, ${ }^{2 / 61}$ and has earned universal support in doing so. ${ }^{262}$ These are compelling reasons to think that the advocates of a substantive right to environment have not, in fact, engaged in the questionable practice of deriving new rights from existing ones.

Third, Handl's classical approach to international law arguably overstates the constraints on development of new law and consequently impedes the evolution of international law necessary to meet increasingly complex challenges, particularly in the area of regulating the global environment. Handl's contention against a soft law formulation of a substantive right to environment implies that soft law can never create rights or obligations. He is unwilling to interpret unanimous endorsement of a nonbinding instrument as "evidence of unequivocal support by states." At the same time, soft law instruments'

${ }^{257}$ Handl, supra note 146 , at 126.

258 Id.

259) See supra notes 176-81 and accompanying text (demonstrating the point in the context of a procedural right to environment).

Seiv supra notes 76-98 and accompanying text (describing the disproportionate extent to which poor communities are affected by environmental degradation).

${ }^{261}$ See supra notes 234-37 and accompanying text (outlining these principles and their connection to current international environmental protection).

${ }^{262}$ See supra notes 56-63 and accompanying text (describing the agreement among nations forged at the Earth Summit over the rights and responsibilities regarding sustainable use).

263 Handl, supra note 146, at 127. 
satisfying this standard through "explicit state practice"2iin — signifying state consent and the expectation of adherence-means the soft law instruments did not create law as much as codify it. Luis RodriguezRivera explains that the traditionalist scholars Handl epitomizes both ignore the trend of international law and deny the advantages of using soft law. ${ }^{20 i 5}$

Rodriguez-Rivera observes that "modern international law has evolved into a more political and diplomatic order, and less of a legal order." "2iii Consequently, deterrent value is found not just in legal recourse alone, but also in states' "desire [for] a reputation [of] principled behavior... [and] relations with other countries to be friendly." international agreements that render states presumptively no less inclined to comply with them than with binding agreements. ${ }^{2 l i s}$ The practical implication of this political order is that states take soft law documents very seriously. ${ }^{269}$ Additionally, the international community has grown to favor soft law instruments as "the preferred legislative approach" in regulating international affairs, thus inferring broad recognition of their influence. ${ }^{271}$

The effectiveness of soft law in guiding state conduct does not fully account for its popularity. The more formal sources of interna-

2604 Id

265. See Rodriguez-Rivera, supra note 71 , at 41 (stating that "[s]ome traditionalist legal scholars would ... emphasize that ... soft law principles do not create rights or obligations").

2itis $l$.

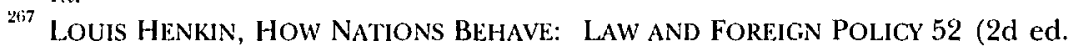
1979).

20K Rodriguez-Rivera, supra note 71 , at 43.

${ }^{2699}$ See id. at 42 (" $[\mathrm{I}] \mathrm{t}$ is clear by the proliferation of soft law documents that states understand that mutual interdependence in the world order necessitates cooperation."). Harold Koh explains the effectiveness of soft law similarly. Koh argues that a state's compliance extends from a realization of its own self-interest to do so. That realization is a product of internalizing international norms achieved by the interaction between states. Koh, supra note 221, at 2655. Many of these norms are codified as soft law.

This is not to suggest that soft law lacks all legal authority: "The 'legal' character of soft law norms . . . derives from both international consent to them and the expectation that nations will make a good faith effort to keep the commitments these norms express." Dernbach, supra note 40, at 86 (citations omitted). At the least, "[a] country's agreement to a soft law instrument also relinquishes any right the country may have to say that its actions concerning the matter are only of domestic concern." Id. at 86-87 (citations omitted). At the most, soft law is one stage along a continuum of increasing normative force that ends with binding international obligations.

Rodriguez-Rivera, supra note 71 , at 41 . 
tional law that comprise hard law wield the same threat of political ramifications that motivates states to comply with soft law. ${ }^{271}$ Furthermore, hard law is considered legally binding. ${ }^{272}$ The additional security inherent in hard law to achieve compliance begs for an explanation of why the international community increasingly turns to a soft law approach in developing new law. Rodriguez-Rivera believes the attractiveness of soft law lies in its flexibility. ${ }^{273}$ The issues addressed by soft law are generally complex and controversial-environmental regulation being an archetypal example. In response to these conditions, " " $[\mathrm{s}]$ oft law instruments allow for the incorporation of conflicting standards and goals." ${ }^{274}$ What then soft law often represents, and speaking more specifically to the Rio Declaration and its associated documents, is an agreement on general principles.

It is difficult to see how the competing demands on natural resources could accommodate more specific legal restrictions. Returning to the example of Cambodia, its forestland offers the antithetical possibilities of sustaining local communities or increasing national industrial development. ${ }^{275}$ The guidelines of sustainable development certainly prioritize environmental protection and ensure a role for dependent communities in the decision-making process. Sustainable development does not, however, mandate a specific outcome. As a result, it remains compatible with the reality that both agendas are justified and worthwhile, and does not foreclose potential compromises that deal with such difficulties.

What remains debatable within these parameters are the practical details to achieve the general principles of sustainable development and the authority to demand adherence. ${ }^{276}$ Admittedly, the flexibility of soft law, painted as a beneficial characteristic by RodriguezRivera, ${ }^{277}$ means it is prone to a degree of confusion and uncertainty.

271 A state's desire for a reputation as internationally law abiding and for constructive international relations is similarly at risk if the state violates hard, as opposed to soft, law. Intuitively, a state's motivation to achieve these political goais would be stronger in matters implicating hard law.

${ }_{272}$ See Rodriguez-Rivera, supra note 71 , at 37 (explaining that the formal sources of international law are understood as creating rules of general application with legally binding effect).

Id. at 41 .

${ }^{274}$ Id. at 42 (quoting C.M. Chinkin, The Challenge of Soft Law: Development and Change in International Law, 38 INT'L \& COMP. L.Q. 850, 866 (1989)).

${ }^{275}$ See supra Part I.B (noting Cambodia's dual reliance on its forestland to sustain local population and to entice needed development projects).

${ }^{226}$ Carlson, supra note 164 , at 1204.

${ }^{277}$ Rodriguez-Rivera, supra note 71 , at 41-42. 
However, Rodriguez-Rivera suggests that the ambiguity of soft law is what renders it possible for the international community to engage in sensitive environmental rule making at all. ${ }^{274}$

Part III.B describes other criticisms levied against a substantive right to environment, including that the right is redundant, its ambiguity renders it unworkable on a practical level, and its enforcement through international bodies capable of adjudicating human rights issues and implementing determinations is misplaced. These concerns are each addressed in turn.

Any claim that a substantive human right is redundant is addressed by considering the approach adopted by the international community to achieve sustainable development. As discussed, sustainable development relies on the mechanism of public participation. However, public participation amounts to little if states have no incentive to take it seriously - a void filled by a substantive human right to environment.

As to the inherent difficulty in defining a right to environment, it is worth mentioning that the current analysis in no way seeks to depart from a conception of the right to environment that emphasizes procedural rights. The substantive aspect of the right to environment should be acknowledged in theory and should act principally as a deterrent in practice. As such, a substantive right to environment reflects a crucial component to realizing an objective of the Rio Declaration to empower populations. At the same time, procedural rights remain the fundamental mechanism through which inhabitants need to exert their authority.

Still, states will fail to make a reasonable attempt at integrating sustainable development in their decision making and thus will test international commitment to protecting a substantive right to environment. These instances should not prove abnormally difficult for international enforcement bodies to handle. First, uncertainty is a common feature of most human rights. ${ }^{279}$ Second, international bodies have historically proven capable of formulating the requisite specificity for abstract legal terms in order to make them work. ${ }^{2 \times 0}$ The International Court of Justice has unhesitatingly begun to build its

278 See id. at 45 ("Soft law instruments are necessary in the development of international environmental law given the technical complexities and the conflicting economic values involved in addressing global environmental problems.").

270. at 11 .

ld. at 13. 
jurisprudence concerning sustainable development, which encompasses the aims of a right to environment. Judge Higgins observes:

What is apparent from ... review of the cases which have come before the International Court . . . is the change in focus from disputes about concessions and control of natural resources to disputes about sustainability and the limits of resource use. This development suggests the Court's continued importance in the evolution of general international law in this field ....

Finally, it should not be forgotten that ambiguity is ultimately an asset of a right to environment. Justifying the right depends on shaping it around the social, economic, and cultural context in which it is exercised. $^{\text {2R2 }}$ International monitoring bodies are certainly at a disadvantage compared to national court systems in this regard, but they are hardly incapable. Most important is an appreciation of the role that context plays in understanding the right. It stands as a considerable safeguard against the cultural imperialism that Boyle believes is the inevitable result of any strict formulation of the doctrine.

Should a right to environment become accepted into the body of the international human rights law, it would provide rights-holders several possible international fora for redress by various means-most notably, adjudication and reporting. ${ }^{283}$ In this way, the substantive

${ }^{281}$ Rosalyn Higgins, Natural Resontces in the Case Law of the International Court, in INTERNATIONAL LAW AND SUSTAINABLE DEVELOPMENT, supra note 58, at 87, 111; see also KISS \& SHELTON, supra note 145, at 24 (proposing that the right to environment will be defined effectively by a tribunal given "that there presently exists in the public conscience a clear image of an environment which should be preserved and from which each person should benefit"). By looking to the ICJ for success in the treatment of sustainable development, I do not mean to suggest that the ICJ is among the avenues available to enforce an individual right to environment on an international level. The ICJ's founding statute limits its competent jurisdiction to disputes between states. See Statute of the Intemational Court of Justice, supra note 165, at art. 34(1) (requiring that "[o]nly states may be parties in cases before" the ICJ). Instead, I evoke the ICJ as an example of an international body that has used the doctrine of sustainable development without floundering. On the other hand, some commentators have called for a lifting of the ICJ's jurisdictional restriction in order to entertain environmental rights litigation. See Pathak, supra note 163, at 241 (arguing that the ICJ should amend its statute to allow jurisdiction over individual environmental causes of action).

2\$2 Wade Mansell \& Joanne Scot, Why Bother About a Right to Derelopment?, 21 J.L. \& SOC'Y 171, 189 (1994).

${ }^{283}$ An incomplete list includes the United Nations Commission on Human Rights, the Sub-Commission of the Human Rights Commission, the Commission on Sustainable Development, and the Economic and Social Affairs Council, not to mention specialized agencies and regional organizations. For an extensive list of international structures for implementation of environmental and human rights policies, see CAlDWEl.L, supra note 52, at 121-57; Laurence R. Helfer, Forum Shopping for Human 
right to environment helps to overcome the political disadvantages undermining the procedural facets of the right. It serves as "the ultimate 'safety net' to catch legitimate claims which have fallen through the procedural cracks of public and private law." ${ }^{244}$ Under an international legal regime devoid of substantive rights, the example of the Pheapimex Concession demonstrates that compliance with the edicts of sustainable development, including public participation, bears a close correlation to the international attention focused on the matter. ${ }^{2 \times 5}$ A substantive right to environment effectively transforms sustainable development from a provision of international environmental law, enforceable only through state-to-state relations, if at all, to a human right enforceable by the individual through international means. Hence, a potential for international influence exists in every state decision over the allocation of natural resources. This, in turn, lends true empowerment to communities reliant on natural resources. States would have a heightened incentive to forge compromise through the participation process and act with greater uniformity from one circumstance to another. For this reason, it can be said that establishing a right to environment containing both procedural and substantive attributes provides a linchpin to implementing the policy of sustainable development on a global level.

\section{CONCLUSION}

In this Comment, I endeavored to make a compelling argument for the existence of an international human right to environment with both a procedural and substantive component. I believe this right to environment is justified based on the international instruments concerning sustainable development, properly described as international consensus on a productive relationship between humanity and our

\footnotetext{
Rights, 148 U. PA. L. REv. 285, 288 (1999); Pathak, supra note 163, at 238-42. Some commentators explore the possibilities of strengthening the enforcement framework in the realm of human rights and the environment. Alexandre Kiss proposes a High Commissioner for Environmental Protection set up by the U.N. General Assembly to, among other responsibilities, receive and assess complaints of international environmental violations and protect the interests of future generations in step with the concept of sustainable development. Alexandre Kiss, An Introductory Note on a Human Right to Enviromment, in ENVIRONMENTAL CHANGE AND INTERNATIONAL LAW, supm note 163, at 199, 203-04.

2x.4 Anderson, supra note 146, at 21-22.

${ }^{285}$ See supm text accompanying notes 223-24 (noting that, in spite of past promises, it took the withdrawal of monetary aid to force Cambodia to control its illegal timber trade).
} 
environment. I have tried to show through the example of Cambodia that the right would prove functionally effective for realizing sustainable development by imposing a greater level of equality with respect to determining natural resource use and would bring state action more in line with its principles. Finally, I have stressed the importance of the issue by presenting the right as an essential element of the enforcement framework developed by the international community for the implementation of sustainable development on a global scale.

A right to environment is hardly the only concern surrounding sustainable development. The struggle for sustainable development is being waged on several fronts. Most recently, at the WSSD, the international community focused on the international facets of achieving sustainable development-securing political will among the states, outlining practical steps for states and the international community to carry forward the agenda of sustainable development, and gaining the funding for these programs. ${ }^{286 i}$ Not to deny the importance of the agenda pursued at the WSSD, we should not mistake its goals for the complete scope of considerations on sustainable development or for the only approach necessary to achieve successful ends.

At the conclusion of the WSSD, Kofi Annan asserted: "Action starts with governments .... Governments cannot do the job alone, however. Citizen groups have a critical role, as partners, advocates and watchdogs." ${ }^{287}$ Thus, the fact that the Plan of Implementation does not significantly advance the right to environment is not tantamount to denying its existence. The Plan of Implementation acknowledges debate over "the possible relationship between environment and human rights." ${ }^{289}$ Further, it essentially directs states to extend the details of the right to their people. The right to environment remains an indispensable factor in the formula for implementing sustainable development. By means of human rights, citizens are made effective "partners, advocates and watchdogs," which, in turn, creates a genuine state

\footnotetext{
${ }^{246}$ Under-Secretary Nitin Desai proposed three objectives for the WSSD, revealing the broad international focus of the summit: political will, practical steps, and partnership. Desai, supra note 49, at 6-7. Once the summit began, the overriding theme that emerged-whether in connection with, or in contravention of, these goals-was money, with "negotiations quickly [becoming] bogged down between impoverished countries demanding more aid and wealthy nations reluctant to give it." Kenneth $R$. Weiss, U.N. Gathering Quickly Tums to Who Will Pay for Ambitions Aims, L.A. TIMES, Aug. 27, 2002, at A3.

${ }^{287}$ Kofi A. Annan, A World to the Wise, WASH. POST, Sept. 2, 2002, at A23.

$2 * 8$ Plan of Implementation, supra note 65 , at para. 152.
} 
obligation to advance sustainable development. With this occurrence among enough communities in enough countries, sustainable development can become a global norm. 